A N N A L E S

UNIVERSITATIS MARIAE CURIE-SKŁODOWSKA

LUBLIN - POLONIA

VOL. LXVI, 2

SECTIO G

2019

Uniwersytet Technologiczno-Humanistyczny im. Kazimierza Pułaskiego w Radomiu

ZBIGNIEW MARKWART

z.markwart@uthrad.pl

ORCID: 0000-0002-1897-1476

\title{
Erazm Piltz o wojnach i ich skutkach dla sytuacji Polski
}

Erazm Piltz on Wars and Its Consequences for Polands Situation

W dobie porozbiorowej kwestia wpływu wojen na sytuację Polski, a szczególnie ich znaczenia dla jej poprawy lub odzyskania niepodległości, musiała siłą rzeczy być jednym z najistotniejszych tematów poruszanych w ówczesnej publicystyce. Wśród różnorodnych poglądów głoszonych przez polskich polityków należy zwrócić uwagę na stanowisko, jakie prezentował Erazm Piltz (1851-1929), jeden z przywódców stronnictwa ,realistów”, zaliczanych do tzw. nurtu „,ugody” z Rosją ${ }^{1}$. Żył i działał w kilku zdecydowanie różniących się etapach dziejów Polski, począwszy od traumy, w której pogrążył się naród po powstaniu 1863 r., przez trwającą kilka lat nadzieję na poprawę bytu pod zaborem rosyjskim, na co wielu Polaków liczyło, spodziewając się tzw. nowej ery w początkach panowania Cesarza Mikołaja II i później, w pierwszym okresie będącej wynikiem wojny z Japonią rewolucji 1905 roku, aż po zawód, którego wówczas znów doznano. Kolejny to lata I wojny światowej, a następnie niepodległej Polski po 1918 r. Jego poglą-

1 Więcej o jego działalności i poglądach w ramach stronnictwa „realistów” zob. m.in. w: A. Kidzińska, Stronnictwo Polityki Realnej 1905-1923, Lublin 2007; Z. Markwart, Polityka realna. Zarys działalności i programu stronnictwa petersburskich realistów (1859-1906), Kraków 2012; idem, Wtodzimierz Spasowicz i petersburscy realiści: apostaci, ugodowcy czy rzecznicy narodu?, [w:] Między realizmem a apostazją narodową. Koncepcje prorosyjskie w polskiej myśli politycznej, red. M. Zakrzewski, Kraków 2015; A. Szwarc, Od Wielopolskiego do Stronnictwa Polityki Realnej. Zwolennicy ugody z Rosją. Ich poglady i próby działalności politycznej (1864-1905), Warszawa 1990. O działalności w latach I wojny światowej zob. A. Szczepaniak, Od autonomii do niepodległości. Działalność polityczna Erazma Piltza w latach 1914-1929, Opole 2015. O jego pracy redaktorskiej w „Kraju” zob. Z. Kmiecik, , Kraj” za czasów redaktorstwa Erazma Piltza, Warszawa 1969; idem, Nowoczesny konserwatysta (Erazm Piltz), „Kwartalnik Historii Prasy Polskiej” 1991, z. 3-4. 
dy na kwestię niepodległości, w tym roli, jaką mogły odegrać dla niej konflikty zbrojne i ich skutki, ulegały zdecydowanej ewolucji: od uznania, że jest ona niemożliwa i dlatego uważał, że należy zabiegać o przyznanie Królestwu samorządu, a następnie od 1905 r. autonomii w ramach Imperium carskiego, aż po bardzo aktywne włączenie się w działalność na rzecz odbudowy suwerenności pod koniec „Wielkiej Wojny”, podczas której był jednym z najbardziej zaangażowanych polskich polityków emigracyjnych. W suwerennej II Rzeczypospolitej, pełniąc w służbie dyplomatycznej znaczące stanowiska, starał się umocnić jej pozycję międzynarodową.

Według Piltza toczone ze zmiennym szczęściem w całych dziejach Polski wojny z wrogimi sąsiadami wywierały dominujący wpływ na jej losy: ,,[...] bywało rozmaicie; byliśmy pod wozem i na wozie, wiodło się nam źle i dobrze, aż wreszcie ulegliśmy”2. Determinowało to geopolityczne położenie:

Odkąd na początku naszej historyi - pisano w redagowanych przez niego i Włodzimierza Spasowicza „Listach Polskich” - Chrobry zakreślił szablą państwowe granice, Polska, otoczona i ze wschodu i z zachodu śmiertelnymi nieprzyjaciółmi, z którymi jednocześnie staczać musiała walki, znalazła się w położeniu, z którego nie wyszła. Możność bronienia się i przeciwko każdej z dwóch niemieckich marchii i przeciw Rusi a potem Moskwie, oraz przeciwko sojuszowi wszystkich trzech potęg, stanowiła dla niej warunek istnienia. Polska nie podołała temu zadaniu, sąsiedzi ją rozebrali ${ }^{3}$.

Broniąc suwerenności lub w celu jej odzyskania walcząc w kolejnych wojnach i powstaniach, została pokonana. Stało się tak dlatego, że Rzeczypospolitej, mającej przestarzały ustrój, zabrakło sił, by „obronić się od pożądliwości sąsiadów"'. Nie były w stanie temu zapobiec nawet spóźnione i niedokończone próby wzmocnienia mocy obronnej przez projektowane reformy Sejmu Czteroletniego, a „ospałość, z jaką odkładano zbrojenie się do ostatniej chwili, egoizm, z jakim odmawiano ojczyźnie podatków na wojsko"s, nie pozwoliły na ich zrealizowanie. $\mathrm{W}$ ostatnich latach bytu państwowego w zmaganiach z mającymi potężne armie ościennymi nowoczesnymi mocarstwami, aby uchronić się przed kolejnymi rozbiorami, a następnie przywrócić niepodległość, ponieśliśmy klęskę. Nie uchroniła przed nią nawet „najbardziej uzasadniona” i „najsłuszniejsza” z wojen, jaką była

2 Scriptor [E. Piltz], Nasze stronnictwa skrajne, Kraków 1903, s. 221. We wszystkich cytatach zachowano oryginalną pisownię i interpunkcję.

3 „Listy Polskie”. Zeszyt próbny pisma poświęconego sprawom politycznym polskim w ogóle i sprawom Królestwa w szczególności, Kraków 1904, s. 21-22.

4 E. Piltz, Politya rosyjska w Polsce. List otwarty do kierowników polityki rosyjskiej, Warszawa 1909, s. 15; Scriptor [E. Piltz], op. cit., s. 264-265.

5 Scriptor [E. Piltz], op. cit., s. 153. Zob. także: „Listy Polskie”. Zeszyt próbny..., s. 70. 
ta z 1792 r., gdy „Rzeczpospolita miała i prawo i obowiązek wystąpić z bronią w ręku" przeciwko rosyjskiej interwencji. Jednak, mimo że państwo upadło, pozytywem było to, że trzeci rozbiór ,jak piorun, oczyścił atmosferę. Nowe pokolenie, dojrzewające w chwili strasznego kataklizmu, ocknęło się przerażone"’. Przebudziło się wówczas ,sumienie narodowe, rozgorzała miłość ojczyzny i proces ten wyraził się w walkach o zdobycie napowrót własnego państwa [...]"8. Początkiem tej przemiany była wojna, którą toczyła z Rosją konfederacja barska. Mimo że, będąc „typowym obrazem zaślepienia, zarozumiałego przeceniania sił własnych [to stała się objawem - Z.M.] odrodzenia prawdziwych cnót obywatelskich”, podobnie jak powstanie kościuszkowskie, które „ocaliło honor narodu” ${ }^{\prime 0}$. Następnie „zaczął się długi okres tułactwa, siania kości polskich po całej kuli ziemskiej" "11, walcząc nie zawsze bezpośrednio o wolność Polski i o polską sprawę ${ }^{12}$. I choć wojny u boku Napoleona i ta z Rosją, która nastąpiła w wyniku powstania 1830 r. (mająca szanse na zwycięstwo, bo można było wówczas liczyć, że „30-tysięczna armia polska, przechowująca świetne tradycye legionów [...] bić się będzie dzielnie”13), zostały przegrane, to jednak stały się „odrodzeniem duszy polskiej"14. Polacy:

[...] naród, który przeżył tyle wieków potęgi państwowej [...] nie chciał złożyć broni, dopóki nie wystrzeli ostatniego naboju - a następnie, chociaż te wszystkie porywy były pod względem politycznym nie tylko daremne, ale i zgubne, gdyż spychały go ze szczebla na szczebel, odzierając go z resztek państwowości i odrębności politycznej, to jednak naród, jako naród, wyszedł z tych burz z zyskiem moralnym, odrodził się i uszlachetnił $[\ldots]^{15}$.

Te wojny i powstania, choć będące „koniecznością dziejową”" nak lekkomyślnością i z góry skazane na klęskę. Wybuchały w niewłaściwych momentach, bez właściwego przygotowania i źle je prowadzono ${ }^{17}$. Kolejny raz „fatalistycznie powtarzający się w naszych porozbiorowych dziejach, okazało się, że naród nasz w fizycznych zmaganiach się z wielokroć silniejszym od niego

6 Scriptor [E. Piltz], op. cit., s. 153.

E. Piltz, Politya rosyjska w Polsce..., s. 15.

Ibidem.

9 Scriptor [E. Piltz], op. cit., s. 153. Por. „,Listy Polskie”. Zeszyt próbny..., s. 45-46.

${ }^{10}$ Scriptor [E. Piltz], op. cit., s. 154.

11 „Listy Polskie”. Zeszyt próbny..., s. 23.

12 Scriptor [E. Piltz], op. cit., s. 129, 135-136, 170; , Listy Polskie”. Zeszyt próbny..., s. 42.

13 Scriptor [E. Piltz], op. cit., s. 154.

14 E. Piltz, Politya rosyjska $w$ Polsce..., s. 15.

15 Ibidem.

16 „Listy Polskie”. Zeszyt próbny..., s. 3.

17 Scriptor [E. Piltz], op. cit., s. 152-163. Por. „Listy Polskie”. Zeszyt próbny ..., s. 5: „W r. 1830 żaden wyższy oficer nie wierzył, żeby starcie z Rosyą mogło się zakończyć zwycięstwem polskiej broni”. 
organizmem, nie tylko nie odzyska wolności, ale przeciwnie, trwając w uporze, tracić będzie swe siły, swą krew, będzie ubożeć i marnieć"18, a kolejne terytoria wraz z ich ludnością dostały się pod obce panowanie. Trzeba więc wreszcie uznać, że nadszedł kres tych krwawych zmagań, bo naród zrozumiał, że nie może „wiecznie użyźniać niw europejskich krwią, płynącą mu z serca"19. Tym bardziej dziś, nie mając własnego państwa i armii, które utraciliśmy po powstaniu listopadowym, gdy nie wykorzystano szans, jakie dawała nam po 1815 r., co prawda ograniczona, ale jednak konstytucyjna państwowość ${ }^{20}$, nie możemy - co według Piltza oczywiste - już toczyć wojen z zaborcami o suwerenność, a inne drogi do tego celu nie doprowadzą. Państwo polskie upadło więc bezpowrotnie i jego restauracja nie jest możliwa, gdyż niepodległość można było wcześniej obronić, a obecnie odzyskać tylko na drodze walki zbrojnej - „krwią i żelazem”, co jest nierealne ${ }^{21}$. Dlatego trzeba pogodzić się z życiem pod zaborami i bronić w każdym z nich - szczególnie w Królestwie Polskim - zagrożonego bytu, jednocześnie starając się uzyskać status równouprawnienia z poszanowaniem odrębności narodowej i kulturowej, tak jak udało się to osiągnąć od lat 60 . w Galicji. Ta teza była głównym założeniem programowym ,realistów” i ich lidera E. Piltza ${ }^{22}$.

Oceniając możliwość odzyskania suwerenności środkami militarnymi, Piltz uważał, że nie uda się jej przywrócić w wyniku zbrojnej irredenty. Uzasadniając tę tezę, dowodził, że kolejne powstanie skończyłoby się jeszcze większą katastrofą niż poprzednie i nie tylko utratą dotychczasowych praw, lecz wręcz zagładą biologiczną narodu ${ }^{23}$, bo stosunek naszych sił wobec zaborców jest coraz bardziej niekorzystny. Jesteśmy bezsilni, gdyż w Królestwie „na straży spokoju stoi

18 SWL [E. Piltz], Obrachunek, Poznań 1908, s. 13; Scriptor [E. Piltz], op. cit., s. 162.

19 Scriptor [E. Piltz], op. cit., s. 357; , Listy Polskie”. Zeszyt próbny..., s. 3.

20 „Listy Polskie”. Zeszyt próbny..., s. 62; Scriptor [E. Piltz], op. cit., s. 42.

21 Swojak [E. Piltz], Wobec wojny. Głos z Warszawy przez Swojaka, Kraków 1904, s. 21. Por. „Listy Polskie”. Zeszyt próbny..., s. 69: „W długim szeregu powtarzanych bezowocnych zbrojnych wybuchów wystrzelaliśmy ostatecznie wszystkie nasze ładunki. Pozostały nam w rękach tylko papierowe pukawki do dziecinnych jedynie igraszek zdolne".

22 Zob. np. E. Piltz, Politya rosyjska $w$ Polsce..., s. 66-67; SWL [E. Piltz], op. cit., s. 14; Swojak [E. Piltz], op. cit., s. 21; , Listy Polskie”. Zeszyt próbny ..., s. 62-63; „Kraj” 1905, nr 18 (6/ 19 maja). Być może wpływ na przekonanie o braku szans na odzyskanie niepodległości w wyniku czynu zbrojnego miały losy jego ojca Jana, którego za udział w powstaniu styczniowym skazano na zesłanie na Syberię (Archiwum Akt Nowych, Komitet Narodowy Polski, sygn. 2205, k. 2). Znamienne jest, jak wspominał Stefan Krzywoszewski (Dlugie życie. Wspomnienia, t. 1, Warszawa 1947, s. 65), że „Erazm Piltz, w przystępie gorętszego uniesienia, wyznał mi raz, że gdyby rewolucja w Polsce miała w jego oczach, choćby nikłe szanse powodzenia, bez wahania stanąłby w jej szeregach". Więcej o poglądach Piltza i realistów o niemożliwości odzyskania niepodległości zob. Z. Markwart, Polityka realna ..., s. 169-181.

${ }^{23}$ Zob. m.in. E. Piltz, Politya rosyjska $w$ Polsce..., s. 12 i n., 42-44; Scriptor [E. Piltz], op. cit., s. 152, 154 i n., 351-352, 357-358; „Listy Polskie”. Zeszyt próbny..., s. 3-16; SWL [E. Piltz], op. cit., s. 13-14, 26, 68; Tensam [E. Piltz], W chwili ciężkiej i trudnej, Warszawa 1912, s. 19. Więcej o krytyce irredenty zob. Z. Markwart, Polityka realna ..., s. 172-175. 
czterysta tysięcy wojska i cały czujny aparat rosyjskiej państwowości”"24, a Niemcy, Austria i Rosja zainteresowane ,utrzymaniem obecnego stanu terytorialnego w Polsce” ${ }^{25}$ wspólnie go zdławią, gdyż łączy je „zażegnywanie wspólnych niebezpieczeństw wewnętrznych" 26 . Ponadto „stosunki międzynarodowe i organizacya państw nowożytnych i rozwój militaryzmu tak się ułożyły, że przy nich powstania narodowe i nawet materyalne przygotowania do nich stały się niemożliwością"27. W tej sytuacji hasło „»walka orężna« brzmi dziś, jak krwawa ironia z naszej niemocy”28. Tak więc „na żelazo nas nie stać, a na myśl o utoczeniu krwi polskiej wzdrygnęli się nawet [pisząc o endecji - Z.M.] doktrynerzy nieprzerwalności idei powstańczej"29.

Piltz pisał, że złudzeniem są też żywione przez część narodu rachuby na osiągnięcie suwerenności środkami dyplomatycznymi lub militarnymi przez wsparcie ze strony państw zachodnich, Japonii, a nawet Turcji ${ }^{30}$. Jeszcze przed trzecim rozbiorem rozpoczął się czas:

[...] wyciągania ręki o pomoc ku dalekiemu Zachodowi i przeciwko trzem zaborcom. Spełniony został wielki błąd i grzech, bo powstać skutecznie, chociażby i z cudzoziemską pomocą, mogą tylko te narody, które stać podołają potem o własnych siłach; a żeby się u nas na to zanosiło, nikt $\mathrm{z}$ nas temu nie wierzy ${ }^{31}$.

Uważał, że problem Polski nie istnieje w orbicie ich zainteresowań, gdyż uznały, że jest to wewnętrzna sprawa państw zaborczych, a jej wskrzeszenie zdestabilizowałoby sytuację w Europie, naruszając równowagę sił między mocarstwami. Tak było w czasie powstania i wojny z Rosją w latach 1830-1831, a także kolejnych zrywów niepodległościowych, które wybuchły w „dobie największej reakcyi w Europie i zupełnego zsolidaryzowania się państw rozbiorowych w imię wspólnego niebezpieczeństwa"32. Sporadycznie stawiana podczas konfliktów międzynarodowych przez rządy zachodnie kwestia polska była tylko kartą przetargową w ich politycznej rywalizacji, a nie rzeczywistym poparciem dla odbudowania niepodległej Polski. Dlatego podejmowane przez Narodową Demokrację

${ }^{24}$ Swojak [E. Piltz], op. cit., s. 20; Scriptor [E. Piltz], op. cit., s. 233.

25 „Listy Polskie”. Zeszyt próbny..., s. 109.

26 Swojak [E. Piltz], op. cit., s. 10

27 Scriptor [E. Piltz], op. cit., s. 163.

28 Ibidem, s. 47.

29 Swojak [E. Piltz], op. cit., s. 21. O krytyce poglądów narodowych demokratów dotyczących powstania zob. m.in. Scriptor [E. Piltz], op. cit., s. VI i n., 170, 327-332. Zaznaczał jednocześnie, że choć nie porzucili oni ostatecznie tej idei, to jednak nastąpiła zmiana ich poglądów, gdyż odkładają jego wywołanie na przyszłość, uznając, że obecnie jest ono niemożliwe i skazane na klęskę (ibidem, s. 165-168).

30 Ibidem, s. 168, 177-179; Swojak [E. Piltz], op. cit., s. 9.

31 „Listy Polskie”. Zeszyt próbny..., s. 23; Scriptor [E. Piltz], op. cit., s. 154.

32 Scriptor [E. Piltz], op. cit., s. 154, 176. 
na Zachodzie, a przede wszystkim w Anglii, starania o jej ożywienie i interwencję skończyły się fiaskiem ${ }^{33}$. W redagowanym przez Piltza „Kraju” skonstatowano: „[...] w stosunkach międzynarodowych nikt się z nami nie liczy, to też i my nie liczymy już dzisiaj na nikogo"34.

Polska nie odrodzi się też w wyniku wojny Zachodu z zaborcami, na co w przeszłości (a nawet dziś, w endeckich i niektórych innych środowiskach) naiwnie liczono, spodziewając się od wielu lat „decydującej »wojny na wiosnę «"35. Tak było np. w czasie będącej przejawem „dziecinnego zaufania w obcą pomoc”"36 konfederacji barskiej i w 1792 r., kiedy obiecując antyrosyjski sojusz, król pruski „najbezczelniej Polskę oszukiwał" ${ }^{37}$. Nadzieje na pomoc rewolucyjnej Francji okazały się złudne, jak również wiara znacznej części Polaków, którzy ulegli „hypnozie napoleońskiej”38 w zwycięską gwiazdę Cesarza w wojnach z nimi, a co za tym idzie na restytucję Rzeczypospolitej, skończyła się rozczarowaniem. Nie spełniły się też oczekiwania na interwencję zbrojną Anglii i Francji podczas powstań z 1830 i 1863 r., gdy proszono je o pomoc, która nie nadeszła ${ }^{39}$, choć carat przed 1863 r., licząc się z możliwością wybuchu powstania, „obawiał się wówczas dość poważnie [...] interwencyi mocarstw europejskich na rzecz Polaków" ${ }^{40}$. Mimo że wszystkie z nich (z wyjątkiem Prus) sprzyjały sprawie polskiej, to jednak ich rządy ograniczyły się jedynie do słownych deklaracji poparcia w walce o wyzwolenie i - jak pisał - wyrażających ,problematyczną" sympatię dla Polaków ${ }^{41}$. Nie będą walczyć o Polskę tym bardziej obecnie, w warunkach równowagi europejskiej i gdy ,zmienił się sposób wojowania, zmienił się stosunek sił europejskich, a każda $\mathrm{z}$ tych zmian usuwała odbudowanie Polski na plan coraz dalszy"42, a także z uwagi na to, że w Królestwie sytuacja jest w pełni kontrolowana przez carat, a nastroje powstańcze po pacyfikacji powstania styczniowego i represjach zanikły. Nie pomogą teraz też dlatego, że nie jest to zgodne $\mathrm{z}$ ich interesami politycznymi, a kwestia polska - jak wspomniano - jest dla nich całkowicie obca i zniknęła $z$ ich pola widzenia. Ponadto nie zdecydują się na wojnę z zaborcami, gdyż zdają sobie sprawę ze wzrostu potęgi Rosji, a szczególnie Prus, czego dobitnym przykładem były klęski w wojnach z nimi najpierw Austrii

${ }^{33}$ Swojak [E. Piltz], op. cit., s. 7-8: „Umizgi wszechpolskiego rządu angielskiego nie zostały nawet zauważone". O krytyce nadziei Narodowych Demokratów na pomoc Anglii i Francji zob. m.in. ibidem, s. 25; Scriptor [E. Piltz], op. cit., s. 172, 177-179.

34 „Kraj” 1890, nr 29 (20 lipca / 1 sierpnia).

35 Swojak [E. Piltz], op. cit., s. 8.

36 Scriptor [E. Piltz], op. cit., s. 153.

37 Ibidem.

38 E. Piltz, Politya rosyjska $w$ Polsce..., s. 15.

39 SWL [E. Piltz], op. cit., s. 14; „Kraj” 1896, nr 48 (29 września / 11 grudnia).

40 Swojak [E. Piltz], op. cit., s. 28-29.

${ }^{41}$ Scriptor [E. Piltz], op. cit., s. 47.

42 „Listy Polskie”. Zeszyt próbny..., s. 13. Por. Scriptor [E. Piltz], op. cit., s. 163. 
w 1866 r., a później Francji w 1870 r. i w jej wyniku zjednoczenie Niemiec. Upadły znów wówczas nadzieje wiązane z kolejnym z rodu Napoleonów: „Rok 1870 wytrzeźwił od razu tych, dla których było pewnikiem, nie ulegającym wątpliwości, że z Paryża musi nadejść wielkie hasło zmartwychwstania" ${ }^{33}$. Istniała także garstka Polaków bezzasadnie licząca na pomoc ze strony Niemiec. „Dla nich było wprost rzeczą niepojętą, iżby zwycięskie Prusy nie wzięły z radością na swe barki zadania, któremu pokonana Francya nie będzie mogła sprostać" ${ }^{44}$, choć powinni pamiętać o ich postawie w 1792 r. i o tym, że prowadzą najbardziej antypolską, germanizacyjną politykę ${ }^{45}$. Co więcej, oczywiste jest przecież, że istnieje ścisłe

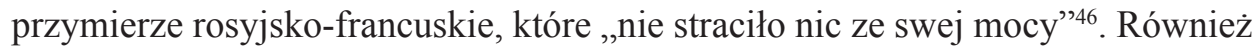
Anglia wyraźnie zmierza do zawarcia sojuszu z Rosją, mimo że zbliżenie polityczne z nią „,nie jest jeszcze faktem spełnionym" ${ }^{47}$. I choć stosunki między nimi mogą się nawet zaostrzyć, to liczyć na nią też nie można, czym łudzą się narodowi demokraci. Zatem obecnie „mrzonka interwencyi obcej znikła prawie do szczętu" ${ }^{48} \mathrm{i}$ „w ogóle nad starą Europą, która nas tyle razy haniebnie zawiodła, trzeba postawić krzyż" ${ }^{49}$.

Złudne są też oczekiwania tych, którzy spodziewają się konfliktu zbrojnego między zaborcami, w wyniku którego powstaną korzystne dla odnowy polskiego bytu państwowego rozstrzygnięcia. Nie dojdzie do niego, bo, po pierwsze - jak wspomniano - żywotnym interesem państwowym każdego z nich jest niedopuszczenie do odrodzenia Polski i dlatego muszą zgodnie współdziałać, a po drugie, nie tylko nie ma żadnych oznak zapowiadających pogorszenie relacji między nimi, ale przeciwnie - twierdził Piltz jeszcze w 1904 r. - coraz pomyślniej się rozwijają. Mimo że wojna z Niemcami byłaby w rosyjskim społeczeństwie „niewątpliwie popularną" ${ }^{50}$, to jednak państwa te, ,granicząc z sobą, o miedzę, mają niezaprzeczenie wspólne interesy sąsiedzkie" ${ }^{51}$, szczególnie dotyczące sytuacji w Polsce. Dlatego Cesarz Niemiec Wilhelm II „od dawna i tak natarczywie [...] przy każdej sposobności jaka się tylko nawinęła" ${ }^{2}$ dąży do większego zbliżenia z Rosją. Z drugim z zaborców, Austrią, ,prowadzi rząd rosyjski w dalszym ciągu wspólną politykę na

43 „Listy Polskie”. Zeszyt próbny..., s. 13.

44 Ibidem.

45 Scriptor [E. Piltz], op. cit., s. 216, 221, 223-225.

46 Swojak [E. Piltz], op. cit., s. 7.

47 Ibidem, s. 8.

48 „Listy Polskie”. Zeszyt próbny..., s. 13.

49 Swojak [E. Piltz], op. cit., s. 8. Podobnie napisano w „Kraju” (1896, nr 48): „Rachuby na pomoc Europy są bolesnem a upokarzającem złudzeniem, które nam nieodzownie zgotować muszą szkodliwe zawody i narazić na fatalne marnowanie drogiego czasu".

50 Swojak [E. Piltz], op. cit., s. 15.

51 Ibidem, s. 10.

52 Ibidem, s. 9. 
półwyspie bałkańskim, datującą się od kilku lat" ${ }^{53}$ i nic nie wskazuje, aby stosunki między nimi miały się pogorszyć. W tym kontekście Piltz w pełni podzielał pogląd swojego mistrza W. Spasowicza, iż mrzonką są nadzieje, że przy pomocy monarchii habsburskiej uda się zjednoczyć w jej granicach ziemie polskie, a następnie wskrzesić państwo. Austria, która jest najsłabszym z państw zaborczych, mająca wielkie problemy z utrzymaniem integralności państwa, spowodowane separatystycznymi dążeniami narodów będących pod jej panowaniem, nie tylko tego nie chce, ale i nie mogłaby tego dokonać, gdyż przyłączenie tak dużej części ziem polskich zwiększyłoby znacznie proporcję ludności słowiańskiej wobec Niemców. Po trzecie, by to zrealizować, musiałaby zdecydować się na wojnę nie tylko przeciwko Rosji, ale i Niemcom, od których po przegranej wojnie z $1866 \mathrm{r}$. jest coraz bardziej uzależniona $^{54}$. Krytykując wszechpolaków, pisano: ,[... [ precz ze śmieszną myślą wytworzenia z ciężkiej i zacofanej Galicyi [...] czegoś na kształt Piemontu polskiego [...]"55. Jeśli jednak którekolwiek z tych państw starłyby się zbrojnie, to konflikt ten stałby się tragedią przede wszystkim dla Polaków, którzy wcieleni do obcych armii ginęliby w bratobójczej walce po przeciwnych stronach frontu ${ }^{56}$.

Taką analizę sytuacji rozwinął Piltz w latach wojny rosyjsko-japońskiej ${ }^{57}$ w wielokrotnie wcześniej cytowanej broszurze Wobec wojny, którą opublikował anonimowo w Krakowie w początkach czerwca 1904 r., jak również w innych publikacjach. Zawarta w niej była przede wszystkim bardzo krytyczna ocena poglądów narodowych demokratów wobec konfliktu i - w opozycji do nich - przedstawił stanowisko stronnictwa „realistów”.

W odniesieniu do skutków, jakie wojna może przynieść Polsce, rozpatrywał je w kontekście zarówno stosunków międzynarodowych, jak i wewnątrzrosyjskich.

Opisując i oceniając reakcje na jej wybuch, dowodził, że był on niemal dla wszystkich niespodziewany, tak dla rządów i społeczeństw Zachodu, jak również dla władz i narodu rosyjskiego, a także dla Polaków. Nawet „w Petersburgu nie

53 Ibidem, s. 7.

54 W. Spasowicz, Polityka samobójstwa, samobójstwa. Uwagi nad pisemkiem „Polska i Rosja w 1872 przez b. członka Rady Stanu Królestwa Polskiego”, Poznań 1872, s. 26.

${ }_{55}$ „Listy Polskie”. Zeszyt próbny..., s. 32. O krytyce orientacji Narodowej Demokracji na Austrię zob. m.in. Scriptor [E. Piltz], op. cit., s. 197-214, 226-227. Zob. także: Z. Markwart, Państwa zaborcze i ich polityka wobec Polski w poglądach stronnictwa realistów, „Annales UMCS sectio G (Ius)" 2011, t. 58, s. 9-13.

56 Powtarzał w tej kwestii poglądy swego ideowego patrona W. Spasowicza (Jerzego Moszyńskiego po czterdziestu latach. Szkic polskiej polityki o chwili obecnej, [w:] idem, Pisma, t. 9, Warszawa 1908, s. 63-64), który pisał: „Bylibyśmy przedewszystkiem przy starciu takiem zmiażdżeni, szczególnie gdyby tak się stało, żeśmy wojnę tę poduszczali i które z tych mocarstw na drugie naprowadzali”. Podobnie: idem, Jubileusz Kraszewskiego, [w:] idem, Pisma, t. 6, Petersburg 1892, s. 101; idem, Polityka samobójstwa ..., s. 37: „[...] broń nas Boże od wszelkiego politykowania, poduszczania Niemców przeciw Rossyi, albo Rossyi przeciw Niemcom; - wara sadzić palce między drzwi”. Zob. także: idem, Fantazje polskie na tematy stowianofilskie, [w:] idem, Pisma, t. 2, Petersburg 1892, s. 229.

57 Trwała od nocy z 26 na 27 stycznia (8 na 9 lutego) 1904 r. do września 1905 r. 
wierzono w nią do ostatniej chwili" "58. Tym większym zaskoczeniem były klęski armii carskiej, którą uważał za największą potęgę militarną świata ${ }^{59}$. Dlatego we wszystkich państwach, czy to sprzymierzonych z Rosją, czy jej wrogich, „zadawano sobie pytanie, czy dzień 9 lutego 1904 r. nie będzie punktem zwrotnym w historyi świata i początkiem osłabienia mocarstwowego stanowiska Rosyi”" ${ }^{\prime 60}$.

W aspekcie międzynarodowym podtrzymywał konsekwentnie swój pogląd, że jakakolwiek interwencja na rzecz Polski z zewnątrz nie jest możliwa ani W związku z toczoną przez Rosję wojną, ani na wypadek ewentualnego powstania, które chcieli w Królestwie wzniecić socjaliści. „Przekonano się już dawniej - pisał Piltz z perspektywy kilku lat w 1908 r. - że ani pomoc zagraniczna, ani wewnętrzne zbrojne ruchy nie wyzwolą nas ani uratują"61. Liczenie, że państwa Zachodu podniosą kwestię polską, korzystając z osłabienia Imperium podczas wojny, jest obecnie tym bardziej nieuzasadnione, bo - jego zdaniem - wiedzą one, że jego pozycja jest stabilna, a ,wybuch wojny nie tyko nie osłabił międzynarodowej pozycyi Rosyi, ale prawie ją wzmocnił” ${ }^{2}$. Jest to równoznaczne z „bankructwem wszechpolskich rachub na zagranicę. Bezlitosny powiew rzeczywistości rozwiał wątłe pajęczyny wielkich pomysłów" ${ }^{\prime 3}$. Istnieje przecież nadal wspomniane wcześniej jej trwałe przymierze z Francją, współpraca z Austrią, a „,o do Niemiec i Anglii, znalazła się Rosya w niespodziewanem a szczęśliwem położeniu, że prawie wybierać może zbliżenie z jednem lub drugiem z tych państw"64. Odnośnie do Niemiec ostrzegał, że wojna może przyspieszyć sojusz tych państw, szczególnie w sytuacji, gdyby w Królestwie Polskim doszło do antyrosyjskich wystąpień:

Im bardziej byłaby Rosya osłabiona na wschodzie, a zaniepokojona nastrojem na zachodzie, tem cenniejszą musiałaby być dla niej przyjaźń możnego sąsiada [...] a trudno sobie wyobrazić większej klęski dla położenia naszego w obu państwach, dla dalszego obrotu naszych losów, jak odnowienie paktu, który w ciągu stu lat spisywany był zawsze na naszej skórze ${ }^{65}$.

Naiwne są też rachuby wszechpolaków na wsparcie przez Japonię i przymierze z nią, o którym pisali w swych organach prasowych, mimo że ,przecież zjawił się na jakimś balu polskim w Wiedniu attache ambasady japońskiej i mrugał

58 Swojak [E. Piltz], op. cit., s. 3.

59 Piltz, podobnie jak inni „realiści” - jak pisał Krzywoszewski (op. cit., s. 65) - wręcz „zaślepieni byli potęgą Caratu" i uważali Rosję za najpotężniejsze państwo na świecie. Por. W. Feldman, Dzieje polskiej myśli politycznej 1864-1914, Warszawa 1933, s. 164.

${ }^{60}$ Swojak [E. Piltz], op. cit., s. 3.

${ }^{61}$ SWL [E. Piltz], op. cit., s. 14.

${ }_{62}$ Swojak [E. Piltz], op. cit., s. 7.

${ }_{63}$ Ibidem.

${ }^{64}$ Ibidem.

${ }^{65}$ Ibidem, s. 9-10. 
znacząco oczami”" ${ }^{\prime}$. Oceniając to, Piltz ironizował: „Nie sposób, żeby echo tych okrzyków nie doszło do Tokio i Jokohamy i nie wywarło wrażenia [ale-Z.M.] ich urzeczywistnieniu staną zapewne na przeszkodzie niejakie trudności geograficzne" ${ }^{97}$. Krytykując polityczne plany narodowców, doceniał jednocześnie, że porzucili próby wywołania powstania w oparciu o zagranicę ${ }^{68}$. Reasumując, stwierdzał: „Jak widzimy, na najdalszym nawet horyzoncie nie widać ani jednej konjunktury międzynarodowej, któraby, na gruncie wojny rosyjsko-japońskiej i w jej skutku, mogła wpłynąć korzystnie na nasze losy" ${ }^{\prime \prime}$.

Co do skutków wojny rzutujących na sytuację wewnętrzną Rosji i ich wpływu na losy Polski, Piltz zdecydowanie krytykował tezę Narodowych Demokratów, którzy byli przekonani, że niezależnie od jej wyniku, a więc czy Rosja wygra, a szczególnie gdy zostanie pokonana, to przyniesie on pozytywne dla Polaków rezultaty. Twierdzili oni, że w obu tych przypadkach, wyczerpana i osłabiona, a w razie klęski także upokorzona Rosja będzie „zmuszoną”, „zniewoloną” - cytował Piltz ich oświadczenia - „do »zmiany polityki względem narodów uciskanych« i do »liczenia się z nami «"70, a więc do wprowadzenia korzystnych dla naszego narodu głębokich reform wewnętrznych. Wbrew temu, co pisano we wszechpolskich organach prasowych, jak np. w „Polaku”, w którym „wbijają w głowy chłopskie dogmat, że »wojna z Japonią jest dla nas Polaków w każdym razie korzystną «" ", poglądy takie uważał za nieuzasadnione - są one obiecywaniem „złotych gór”, a „po bliższem przyjrzeniu się okazują się zrobionemi z tektury” ${ }^{\prime 2}$. Analizując je, kwestionował też tezę wysuwaną na podstawie kolejnych porażek armii rosyjskiej, że przegra ona wojnę, że „,do samego końca [...] Japończycy będą wciąż rozbijać wojska rosyjskie, a Rosyanie skazani są na nieustanne cofanie się"73. Według niego Rosja jest nadal mocarstwem, a ci, którzy uważają przeciwnie, są w błędzie.

Nie przypuszczają, a przynajmniej w planach swoich nie biorą w rachubę, że wojsko rosyjskie jest liczne i bitne, że za armią mandżurską, stoi w odwodzie parę milionów bagnetów, że siła odporna Rosyi, jak tego uczy historya, jest bardzo wielka [a - Z.M.] nikt znający Rosyę i jej dzieje, nie uwierzy, by mogła ona uznać się za pokonaną, t.j. zgodzić się przestać być wielkiem mocarstwem, nie wyczerpawszy wprzód wszystkich swoich olbrzymich materialnych i moralnych zasobów $[\ldots]^{74}$.

${ }^{66}$ Ibidem, s. 9. Zob. także: „Listy Polskie”. Zeszyt próbny..., s. 189.

67 Swojak [E. Piltz], op. cit., s. 9.

68 Ibidem, s. 22-26.

69 Ibidem, s. 10.

70 Ibidem, s. 11, 27. Podobnie krytycznie oceniał ich stanowisko w tej kwestii już wcześniej, w 1903 r., lecz w odniesieniu do powstań. Zob. Scriptor [E. Piltz], op. cit., s. 334-336.

${ }_{71}$ Swojak [E. Piltz], op. cit., s. 5, 19.

72 Ibidem, s. 18-19.

73 Ibidem, s. 11 (por. s. 23).

74 Ibidem, kolejno: s. 11, 6, 29. Por. „Listy Polskie”. Zeszyt próbny..., s. 106. O tym, że narodowi demokraci bezzasadnie uważają Rosję za państwo „nieskończenie słabe” [podkr. - E. Piltz], pisał już wcześniej, w 1903 r. Zob. Scriptor [E. Piltz], op. cit., s. 190. 
Twierdził też, że po wojnie państwo i jego władza nawet mogą się wzmocnić ${ }^{75}$.

Piltz jednak - mimo krytyki zakładanego przez wszechpolaków scenariusza - też dopuszczał, a nawet przewidywał sytuację (lecz nie przesądzał stanowczo), że możliwe jest jednak zreformowanie Rosji w rezultacie wojny, ale z innych przyczyn niż te, na które wskazywała endecja, bo przecież „my, słabi fizycznie, nie zdołamy nic wymódz na potężnem państwie, ani groźbami i szykaną, ani spiskiem" "76. Nie był pewny, czy to nastąpi, a jeśli tak, to nie wiadomo kiedy ani jaki będzie kształt zmian ustroju i ich ewentualnych korzystnych dla Polski skutków. Jak pisał: „Nie ma żadnej pewności, że reformy przyjdą teraz właśnie, albo zaraz po wojnie; nikt nie zdoła przewidzieć w jakiem pójdą tempie i w jakiej dane będą rozciągłości"'77. Uzależnione jest to od dalszego rozwoju sytuacji w państwie, którego nikt nie może teraz przewidzieć, bo konflikt - jak wszystko na to wskazuje będzie długi i zacięty, a przede wszystkim od postawy społeczeństwa rosyjskiego jako reakcji na nią ${ }^{78}$.

Wojna ta - w odróżnieniu np. od tej z Turcją z 1877 r. - była według niego w narodzie rosyjskim początkowo bardzo niepopularna. „Korzyści z zabrania Mandżurii i wybudowania kosztem kilkuset milionów kolei wschodnio-chińskiej wydawały się wielu ludziom bardzo problematyczne. [...] Nikt nie mógł zrozumieć, dlaczego Rosya ma się bić z Japonią"79. Jednak po pierwszych klęskach nastroje się zmieniły i nastąpił ,wielki i powszechny poryw patryotyzmu"80, choć wystawionego, jak nigdy dotąd, na ciężką próbę. Zamilkły wszelkie spory i Rosjanie wobec zagrożenia zjednoczyli się z Cesarzem i rządem: wojna stała się „narodową" ${ }^{11}$. Jednak, jeśli będzie się przedłużać, to patriotyczne uniesienie społeczeństwa zawiedzionego nie tylko brakiem sukcesów, ale wręcz porażką, może się wyczerpać ${ }^{82}$ i wówczas rząd, licząc się z nastrojami narodu, będzie skłonny do reformowania państwa i być może także zmieni swój stosunek do kwestii polskiej ${ }^{83}$. Wynika to z doświadczeń historii nie tylko Rosji, lecz i innych państw (jak np. Austrii, która dopiero po klęsce z Prusami w bitwie pod Sadową z 3 lipca 1866 r. przyznała krajom autonomię), bo „nigdy i nigdzie

75 Swojak [E. Piltz], op. cit., s. 29.

76 „Listy Polskie”. Zeszyt próbny..., s. 68

77 Swojak [E. Piltz], op. cit., s. 17. Zob. także: E. Piltz, O naszem stronnictwie. Przemówienie Erazma Piltza na ogólnem zebraniu Stronnictwa Polityki Realnej odbytem w Warszawie 18 stycznia 1910 r., Warszawa 1910, s. 20-21.

78 Swojak [E. Piltz], op. cit., s. 14. Por. ibidem, s. 4, 19.

79 Ibidem, s. 15.

80 Ibidem, s. 14 i n.

81 Ibidem, s. 15.

82 Ibidem, s. 16-17.

83 Ibidem, s. 19. O zasadach i praktyce caratu wobec Królestwa Polskiego zob. Z. Markwart, Polityka rosyjska wobec Polski do I wojny światowej $w$ ocenie petersbursko-warszawskich realistów, „Annales UMCS sectio G (Ius)” 2012, t. 59, s. 33-63. 
rządy absolutne chętnie i dobrowolnie nie uszczuplały swych praw i nie zrzekały się ich na rzecz narodów" ${ }^{4}$. Ale i w przypadku, gdy Rosja wygra wojnę, to istnieje prawdopodobieństwo, że do zmian może dojść. Do takiego przypuszczenia skłaniała go analiza sytuacji w Imperium, bo „w Rosyi od pewnego czasu zaczęło się robić duszno" ${ }^{85}$. Coraz częściej pojawiały się opinie, że wobec narastających problemów w Imperium nie będzie można nadal ich rozwiązywać dotychczasowymi metodami, dopóki carat „swego aparatu państwowego nie

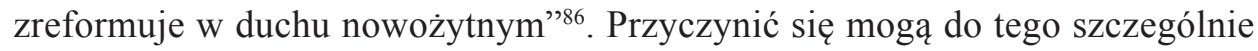
wewnętrzne trudności związane z prowadzeniem wyczerpującej wojny, która „nie może minąć bez wzruszenia różnych społecznych i politycznych przęseł i wiązań w budowli państwowej" ${ }^{87}$. Taka teza - a więc co do przyczyn nieco inna niż formułowana przez wszechpolaków - była jednym z podstawowych punktów programu Piltza i „realistów”, którzy przez cały czas swej działalności uzależniali od naprawy ustroju możliwość poprawy losu Polaków żyjących w jej granicach. Wraz z rozwojem sytuacji, tak jak w innych państwach, wcześniej czy później zmiany systemu „będą więc naturalnym etapem dziejowego procesu" ${ }^{88}$. Nie jest to jednak jego zdaniem - jak wcześniej wspomniano - pewne, że Cesarz i rząd zdecydują się na to wkrótce. Zwracał uwagę także na kształt tych ewentualnych reform. „Jeżeli przyjdą, to podług wszelkiego prawdopodobieństwa nie będą skrojone na wzór europejski, wedle konstytucyjno-parlamentarnej modły, która w Rosyi, nawet w sferach liberalnych, nie budzi wielkiego zapału" ${ }^{89}$. Wynika to z jakże różnej od zachodnioeuropejskiej specyfiki warunków panujących w tym państwie, choć zapewne naród rosyjski zostanie dopuszczony do udziału w polityce ${ }^{90}$. Jeśliby jednak rząd zdecydował się na zmiany ustrojowe, to - w odróżnieniu od endecji - zwracał uwagę na to, że nie jest pewne, czy obejmą one Królestwo Polskie. Ponadto studził rozbudzane przez wszechpolaków oczekiwania i jego zdaniem nadmierny optymizm, ostrzegając, że nawet gdyby tak się stało, to nie wiadomo czy będą dla Polaków korzystne. Być może - na co miał nadzieję - tak się stanie i carat zrewiduje swoją politykę wobec narodu polskiego, a wówczas sytuacja się polepszy, ale ostrzegał, że nie jest to przesądzone, bo może też być odwrotnie. Jako przykład takiego niekorzystnego wariantu rozwoju sytuacji podawał Prusy, w których mimo że jest tam ustrój konstytucyjny, parlament oraz wolność prasy i stowarzyszeń, to ucisk Polaków trwa, a nawet się zaostrza. Może tak stać się i w Rosji: „Jeże-

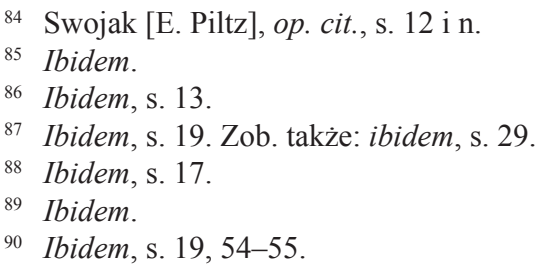


li w jakimś przyszłym »ziemskim soborze« prym weźmie nacyonalizm, to rusyfikacja i prześladowanie narodowości nietylko nie osłabną, ale się wzmogą. Będziemy mieli do walczenia nietylko z biurokracyą, ale i ze społeczeństwem rosyjskiem" ", w którym nawet dawniej sympatyzująca z Polakami część inteligencji i ,rewolucyjne żywioły [...] stoją na gruncie idei państwowej i przeprowadzenie wszelkich politycznych i społecznych zmian wyobrażają sobie w granicach jednolitego, dzisiejszemi granicami określonego państwa rosyjskiego"92. Dlatego tak ważne jest, jaką postawę zajmą Polacy wobec wojny, a szczególnie porażek jej armii. Podobnie, jak pisał Piltz w 1903 r. ${ }^{93}$, w „Kraju” podkreślano, że „W obrębie państwa pod kątem wojny patrzą specjalnie na nas - rosjanie" "94. Zarówno władze, jak i społeczeństwo, oceniając zachowania narodu, wnioskują o naszym stosunku do państwa, co będzie rzutowało na ich ocenę Polaków, a w rezultacie politykę rządu. Pomyślne dla nas rozstrzygnięcia są więc uzależnione od tego, ,jak rząd rosyjski i współrządne społeczeństwo rosyjskie zapatrywać się będą na stan umysłów w Polsce, na szanse polityki pojednawczej"95.

Analizując ówczesne nastroje społeczne, Piltz pisał, że tuż po jej wybuchu w Królestwie niemal powszechna była radość z klęsk Imperium:

Pierwsze wrażenie było wrażeniem wewnętrznego zadowolenia, że państwo, które trzyma naród polski w żelaznych kleszczach praw wyjątkowych i powstrzymuje jego rozwój narodowy zostało zachwiane w swej potędze i głęboko zranione w swej dumie. Przed oczami polskiemi błysnęła wizya historycznej Nemesis, która po długich latach oczekiwania przychodzi nareszcie pomścić nasze krzywdy i bóle $[\ldots]^{96}$.

Podsycana była nie tylko przez narodowych demokratów, ale przede wszystkim przez socjalistów, do których haseł „,nastrój narodowych mas polskich przy pierwszych porywach socyalno-rewolucyjnych przeciwko systemowi rządowemu i jego organom - był dla tych porywów prawie życzliwy"97. Podobnie oceniał to po kilku latach:

Kiedy każdy huk zwycięskich dział japońskich zdawał się wstrząsać kolumnami, na których wspierała się państwowa potęga Rosji, każdy, kto budował przyszłość na tych nadziejach, rósł w dumę i pewność siebie, widział w spełniających się faktach dowód wyższości i mądrości swych teoryj i słuszności swych przewidywann ${ }^{98}$.

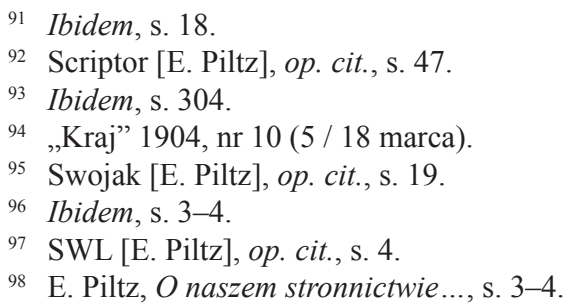


Lecz jego zdaniem:

[...] to pierwsze uczucie trwało tylko krótką chwilę. Musiała przyjść refleksya, że życzyć sobie klęsk rosyjskich nie jest zbyt roztropnie, bo skoro jesteśmy organiczną częścią rosyjskiej całości, więc klęski jej muszą nieuchronnie odbić się i na nas, muszą stać się i naszemi klęskami".

Oczywiste dla niego było, że satysfakcja z klęsk wojsk rosyjskich, a tym bardziej jej ostentacyjne okazywanie, jest wielkim błędem. Nie można tak uważać, oczekiwać tego ani tym bardziej czynić, gdyż w armii carskiej służy około 30 tys. Polaków, a wobec przewidywań wojna będzie długa i krwawa, więc zginie ich setki, a nawet tysiące, „bo nie odróżnią ich i nie oszczędzą kule japońskie" choć w telegramie do posła japońskiego w Wiedniu apelowała o to grupa ,zapalnej młodzieży", zapewniając go, że wszyscy polscy żołnierze są sercem z Japonią. Pamiętać należy również o tym, że na Dalekim Wschodzie mieszka wielu rodaków pracujących na kolei, w przedsiębiorstwach prywatnych i administracji, których życiu i mieniu także grozi niebezpieczeństwo. Nawiązując do stanowiska Ligi przedstawianego w kolejnych manifestach i apelach o demonstrowanie antyrosyjskich nastrojów, Piltz konstatował: „Na samą myśl o tem serca polskie powinny zabić raczej trwogą i smutkiem, niż »radością« [...]"101. Zwracał uwagę też na to, że oprócz ofiar ludzkich wojna spowoduje z pewnością ogromne straty materialne, do których w przypadku porażki Rosji należy doliczyć ewentualne reparacje wojenne, a znaczna ich część obciąży przecież skromny budżet Królestwa ${ }^{102}$.

Jakie więc powinno być właściwe stanowisko narodu i jaką postawę należy przyjąć wobec wojny? Nie można być biernym i neutralnym, jak znaczna część doświadczonej, politycznie wykształconej inteligencji ${ }^{103}$. Pisał, że musimy być przygotowani na każdą ewentualność, by żadna nas nie zaskoczyła, gdyż nie wiadomo jak dalej potoczą się wydarzenia ${ }^{104}$. Nie ma przecież pewności, że wojna ani nawet możliwe do ziszczenia liberalne reformy ustroju państwa zagwarantują nam lepsze warunki bytu narodowego, a - jak wspomniano - mogą je jeszcze pogorszyć, ,jeżeli opuści nas rozum i spokój” ${ }^{105}$. Należy szukać „,właściwej drogi postępowania w nowych warunkach, które wytworzą nie dające się dziś przewidzieć wypadki”'106. Trzeba legalną, spokojną, codzienną i wytężoną pracą zabie-

99 Swojak [E. Piltz], op. cit., s. 4. Podobnie zob. także: SWL [E. Piltz], op. cit., s. 4: „Ale hypnoza musiała mieć kres".

${ }^{100}$ Swojak [E. Piltz], op. cit., s. 5.

${ }^{101}$ Ibidem.

${ }^{102}$ Ibidem, s. 5-6.

${ }^{103}$ Ibidem, s. 31-33, 49.

104 „Listy Polskie”. Zeszyt próbny..., s. 66.

${ }^{105}$ Swojak [E. Piltz], op. cit., s. 19.

106 Ibidem. 
gać o poprawę narodowego bytu w ramach „wspólności państwowej z Rosyją"107. Nie można ulegać postawom zalecanym przez Narodowych Demokratów czy socjalistów, nie można demonstrować antyrosyjskich nastrojów, cieszyć się z klęsk armii ani nawet jako tzw. neutralni pozostawać obojętnymi wobec toczącego się konfliktu, bo nie tylko czynne, lecz i bierne:

[...] zachowania się społeczeństwa polskiego wobec Rosyi, zwłaszcza w takiej chwili przełomowej, historycznej, jak obecna, może być zarówno usprawiedliwieniem ucisku, jak i dowodem jego szkodliwości dla państwa, może być argumentem zarówno przeciw nam, jak i za nami. [...] W tej chwili nastrojem ogółu polskiego interesują się prawdopodobnie tylko prokuratorya i policja rosyjska; Ale może przyjść chwila, którą przewidują nawet urodzeni pesymiści, chwila, na którą czekaliśmy od lat czterdziestu, mogą zajść zmiany w wewnętrznym ustroju państwa rosyjskiego, wraz z niemi zaś stanąć może na porządku dziennym kwestya stosunku do nas, a wtedy pytanie: co leży na dnie nastroju polskiego? - zada sobie polityka rosyjska, rząd rosyjski i, przedewszystkiem społeczeństwo rosyjskie, które przy tych reformach przyjdzie do głosu ${ }^{108}$.

Prawdopodobna w kontekście antypaństwowych postaw ich ocena będzie taka:

Robiliście powstania i spiski, walczyliście nieustannie z państwem, wiązaliście się z jego nieprzyjaciółmi, dążyliście do oderwania się. Kiedy przyszła wielka i nieszczęśliwa wojna [1904 - Z.M.], a za nią rewolucja, zachowywaliście się wrogo. Polityka rosyjska wobec was - to tylko naturalne przeciwdziałanie. Bronimy się i zabezpieczamy. Musimy was osłabiać i niszczyć, gdyż zagrażacie spokojowi i całości państwa ${ }^{109}$.

Dlatego w ostrych słowach Piltz potępiał - podobnie jak w większości swej publicystyki - działalność Narodowych Demokratów polegającą na manifestowaniu antyrosyjskości i okazywaniu radości z klęsk wojennych, bo z pewnością rozbudzi to antypolskie nastroje i może stać się pretekstem do zaostrzenia kursu władz. Według niego dwie siły, czyli „nacyonalizm i szowinizm wszechpolski ze swoim dogmatem nienawiści plemiennej, ze swemi manifestacyami na cześć wrogów Rosyi, pracują gorliwie nad tem, aby naród rosyjski zmusić do »rachowania się« z nami, jako z nieprzyjaciółmi”"110.

Jeśli - jak wspomniano - zgodnie z programem „realistów” Polacy muszą pogodzić się z faktem życia w ramach państw zaborczych, to jako naród musimy znaleźć „,modus vivendi między społeczeństwem polskiem, gorąco przywiązanem do swej narodowości i wiary, pragnącem żyć życiem normalnem i rozwijać się indywidualnie, a państwem, które nabierze przekonania, że nadanych nam praw

${ }^{107}$ Ibidem, s. 21; ,Listy Polskie”. Zeszyt próbny..., s. 109-113.

${ }^{108}$ Swojak [E. Piltz], op. cit., s. 54-55. Zob. także: , Listy Polskie”. Zeszyt próbny..., s. 68-69, 109, 110, 176 i n.

${ }^{109}$ E. Piltz, Politya rosyjska w Polsce..., s. 11-12.

${ }^{110}$ Swojak [E. Piltz], op. cit., s. 18. Zob. także: ibidem, s. 54. 
i warunków narodowego rozwoju nie wyzyskamy przeciw niemu"111. Nie wykorzystano tej szansy w konstytucyjnym Królestwie Polskim i zniweczono przez powstanie styczniowe reformy Aleksandra Wielopolskiego ${ }^{112}$. Musimy nie tylko bronić zagrożonego bytu narodu, lecz także zabiegać o jego rozwój we wszystkich dziedzinach pod zaborem rosyjskim, jak to się udało osiągnąc dzięki racjonalnej polityce konserwatystów Polakom w Austrii ${ }^{113}$. Zdali sobie z tego obecnie sprawę nawet narodowi demokraci, którzy - wbrew wcześniejszym deklaracjom programowym, że należy w każdej nadarzającej się sytuacji podjąć bezpośrednią akcję $e^{114}$ - zdecydowanie odcinali się od agitacji socjalistów, by wystąpić czynnie przeciwko caratowi, stosując akty przemocy wobec władz, i wzywali jednocześnie do zachowania spokoju. Choć nadal zapewniali w swych publikacjach, że „serca polskie na każde zwycięstwo nad wojskami Rosyi odpowiedzą radosnem biciem", to jednak Komitet Centralny Ligi Narodowej uznał, że nie może „przyjąć roli »czynnego sprzymierzeńca« Japonii”, ostrzegając jednocześnie przed „niewczesnymi wystąpieniami w Królestwie" ${ }^{115}$. Jej poparcie może być wyrażane jedynie $\mathrm{w}$ formie moralnego poparcia w manifestacjach, a także na łamach pism i w odezwach. Doceniał, że z czasem, w kolejnych oświadczeniach, Liga potępiała też apele socjalistów wzywające do bojkotowania mobilizacji i masowej dezercji: „My - cytował Piltz - musimy iść na wojnę. Lekkomyślnem zachowaniem się pogorszylibyśmy nasze położenie" ${ }^{116}$. Pochwalał tę ewolucję ich programu, sądząc, że zbliżyli się do poglądów „realistów”"117. Mimo ostrej krytyki i wielu negatywnych uwag pod adresem wszechpolaków wskazywał zatem, że ich przywódcy wreszcie „otrzeźwieli”"118 i nie tylko nie zamierzają wykorzystać nowej - wydawałoby się korzystnej według ich wcześniejszych planów - sytuacji, by wywołać kolejne powstanie, lecz wręcz przeciwnie - występują przeciwko takiej koncepcji.

W oparciu o wyznawane przez Piltza zasady racjonalnej polityki polskiej w granicach imperium rosyjskiego oczywiste było, że jako jeden z liderów „re-

111 Ibidem, s. 19.

112 E. Piltz, Politya rosyjska w Polsce..., s. 16-19; Scriptor [E. Piltz], op. cit., s. 151.

${ }_{113}$ Scriptor [E. Piltz], op. cit., s. 215.

114 Zob. np. ibidem, s. VI i n., 170, 327-332.

${ }^{115}$ Swojak [E. Piltz], op. cit., s. 9, 4. Zob. także: E. Piltz, Politya rosyjska w Polsce..., s. 24 i n.

${ }^{116}$ E. Piltz, Politya rosyjska $w$ Polsce..., s. 24.

117 Swojak [E. Piltz], op. cit., s. 7, 24-26 i n.; E. Piltz, O naszem stronnictwie..., s. 7-10, 22. Por. J. Myśliński, Grupy polityczne Królestwa Polskiego w Zachodniej Galicji 1895-1904, Warszawa 1967, s. 285.

${ }^{118}$ Swojak [E. Piltz], op. cit., s. 7, 23-26; E. Piltz, O naszem stronnictwie..., s. 14 i n. Ewolucję ich programu w tej kwestii dostrzegał - jak wspomniano - już wcześniej, pisząc np. w 1903 r.: ,[...] u wielkiego ołtarza wszechpolskiego zaczynają się zjawiać ludzie, którzy krytycznie patrzą na nasze porywy zbrojne w przeszłości i spokojniej oceniają zadania chwili obecnej [...]" (Scriptor [E. Piltz], op. cit., s. 315). Zob. także: ibidem, s. 165-168; E. Piltz, Politya rosyjska w Polsce..., s. 34-37. 
alistów" włączył się w działalność tzw. ugodowców z Królestwa Polskiego, mającą na celu okazanie władzom lojalności ${ }^{119}$. Z jego inspiracji lub przy znaczącym udziale organizowano szereg akcji mających przekonać rząd o poparciu państwa przez polskie społeczeństwo w toczącym się konflikcie, czego ukoronowaniem było ufundowanie ze składek obywatelskich ambulansu medycznego i wysłanie go na front ${ }^{120}$. Aby silniej oddziaływać na władze w celu korzystnego dla Polski uregulowania stosunków w Królestwie, wykorzystując narastający w związku z wojną kryzys w Rosji, podjął od marca 1904 r. wraz ze Spasowiczem wspierane przez konserwatystów krakowskich starania mające doprowadzić do utworzenia na bazie istniejącego od połowy lat 90. nieformalnego stronnictwa „realistów”, ugrupowania obejmującego wszystkie frakcje ugodowe z zaboru rosyjskiego. Według jego wskazań powstały założenia programowe zatytułowane Wskazania polityczne na dobę dzisiejsza, powtarzające głoszone przez niego od lat główne idee ${ }^{121}$.

Przedłużająca się wojna japońska i rosyjska klęska, która „pochłonęła pół miliona żołnierza i dwa miliardy rubli, bez jednej wygranej bitwy, klęska w dziejach świata prawie bezprzykładna" ${ }^{22}$, „wielka i upokarzająca katastrofa" ${ }^{23}$, której wynikiem była zapoczątkowana „krwawą niedzielą” w Petersburgu 9 (22) stycznia rewolucja 1905 roku, podważyła (choć na krótko) wiarę Piltza w mocarstwowość Rosji. „Po raz pierwszy - pisał - zachwiał się naprawdę »kolos na glinianych nogach «, zadrżała »ścięta mrozem lecąca kaskada« i zdawało się, że ma się istotnie "pod koniec starożytnemu światu«" 124 . Przyznawał, że oczywiste się stało, iż nie jest tak potężna, jak się niemal wszystkim wydawało. Było to wynikiem anachroniczności i wad unormowań ustrojowych oraz założeń ideowych i praktyki, na których opierał się system polityczny caratu, co było także przyczyną polityki władz wobec Polaków. Choć - jak wspomniano - jeszcze w 1904 r. twierdził, że Rosja w wyniku wojny, kryzysu i ewentualnych w ich wyniku przeobrażeń społecznych nie tylko nie osłabnie, lecz wręcz przeciwnie - dzięki reformom wzmoc-

119 Więcej o działalności Piltza i realistów w latach wojny i rewolucji 1905-1907 zob. A. Szwarc, op. cit., s. 336-366; A. Kidzińska, op. cit., s. 33-113; Z. Markwart, Polityka realna ..., s. $115-144$.

${ }^{120}$ Swojak [E. Piltz], op. cit., s. 40 i n.; E. Piltz, O naszem stronnictwie..., s. 17; idem, Politya rosyjska w Polsce..., s. 67 i n.

121 „Listy Polskie”. Zeszyt próbny..., s. 108-113. Zob także: E. Piltz, O naszem stronnictwie ..., s. 10-11; „Przegląd Wszechpolski” 1904, nr 7. Więcej zob. A. Kidzińska, op. cit., s. 33-70; Z. Markwart, Polityka realna ..., s. 115-144; A. Szwarc, op. cit., 336-353; I. Pawłowski, Stronnictwa i programy polityczne w Królestwie Polskim 1864-1918, t. 2, cz. 1: (1900-1907), Warszawa 1964, s. 191-192.

${ }^{122}$ SWL [E. Piltz], op. cit., s.6.

${ }^{123}$ E. Piltz, Politya rosyjska $w$ Polsce..., s. 24.

${ }^{124}$ SWL [E. Piltz], op. cit., s. 6. 
ni się 225 , co być może niekorzystnie odbije się na jej postępowaniu wobec Polski, to teraz już z pełnym przekonaniem twierdził, że „rozpada się i wali w gruzy system i ustrój, który zmorą długoletniego ucisku legł na piersiach narodu" ${ }^{126}$. W związku z tym był przekonany, że tym razem, inaczej niż po wstąpieniu na tron Mikołaja II i zapowiadanej przez niego „nowej erze” w stosunku do Królestwa Polskiego ${ }^{127}$, dojdzie do głębokich zmian ustrojowych i „zeuropeizowania” Rosji, co przyniesie pozytywne skutki nie tylko dla całego państwa, ale spowoduje także przewartościowanie polityki wobec Polski. Utwierdzała go w tym ocena sytuacji w społeczeństwie rosyjskim, w którym według niego świadomość o konieczności głębokich reform i „odrodzenia” państwa stała się powszechna we wszystkich jego warstwach ${ }^{128}$. Mimo że zajmował konsekwentnie zdecydowanie antyrewolucyjne, a szczególnie antysocjalistyczne stanowisko, to entuzjastycznie pokładał wiarę w korzystne dla Polski znaczenie reform zapowiadanych przez Cesarza i rząd. Uważał wówczas, że zgodnie z głoszonym od zarania istnienia stronnictwa „realistów” takim założeniem programowym poprawi się wreszcie los Polaków w Imperium. Nadzieje te zdawały się utwierdzać zapowiedzi zawarte w reskrypcie Cesarza z 3 marca 1905 r., w którym zapowiedziano utworzenie Dumy Państwowej, i kolejne w Manifeście z 6 sierpnia jej zwołanie, a następnie, po Manifeście konstytucyjnym z 30 (17) października 1905 r., nadającym jej uprawnienia ustawodawcze, oraz w Ukazie o tolerancji religijnej z 17 (30) kwietnia ${ }^{129}$. Umocniło to jeszcze bardziej polecenie Mikołaja II wydane generał-gubernatorowi Konstantemu Maksymowiczowi, aby opracował projekt reform dla Królestwa ${ }^{130}$.

Ale, podobnie jak po niespełnionych oczekiwaniach na „nową erę” w 1897 r., znów się zawiódł, co wkrótce znalazło wyraz w jego publicystyce: „Burza przeszła, pozostawiając po sobie głęboki upadek ekonomiczny i rozstrój społeczny”'131. Ani wojna, ani jej skutek, jakim były reformy z początków rewolucji, które mimo niewielkich ulg dla języka polskiego w szkolnictwie, poszerzenia możliwości zakładania stowarzyszeń społecznych, gospodarczych, partii politycznych repre-

${ }^{125}$ Swojak [E. Piltz], op. cit., s. 29. O jego ocenie siły władz rosyjskich zob. m.in. E. Piltz, O naszem stronnictwie..., s. 19-20.

${ }^{126}$ SWL [E. Piltz], op. cit., s. 6.

${ }^{127}$ O nadziejach Piltza i ,realistów" na zmianę kursu władz wobec Polaków wiązanych z Mikołajem II zob. Z. Markwart, Polityka realna ..., s. 68-103.

128 „Kraj” 1904, nr 39 (24 września / 7 października). Zob. także: Swojak [E. Piltz], op. cit., s. $12-16$.

129 „Kraj” 1905, nr 32 (12 / 25 sierpnia). W „Kraju” ukazał się wówczas artykuł, w którym pompatycznie stwierdzono: „Wolność idzie, wolność święta. Idzie po kraju naszym świetlana, uśmiechnięta” („Kraj” 1905, nr 42 [24 października / 6 listopada]).

130 „Kraj” 1905, nr 11 (18 / 31 marca).

${ }^{131}$ E. Piltz, Politya rosyjska w Polsce..., s. 5-6. O zawodzie na poprawę położenia Polski w latach 90. zob. Swojak [E. Piltz], op. cit., s. 34-36. 
zentowanych w parlamencie, nie spełniły pokładanych nadziei. Żaden z postulatów zawartych w programie utworzonego wówczas (18/19 października 1905 r.) Stronnictwa Polityki Realnej, który powstał według wskazówek Piltza, nie został przez rząd zrealizowany ${ }^{132}$. Nie tylko nie nadano Królestwu autonomii, ale nawet nie rozszerzono na jego obszar istniejącego już w Rosji samorządu. Carat nie tylko nie osłabł, ale - jak ostrzegał w 1904 r. przed zbyt daleko idącymi nadziejami (choć na krótko w nie uwierzył) - szybko opanował sytuację i wręcz wzmocnił się, co odbiło się niekorzystnie dla Polaków w „Priwisliniu”. Po zdławieniu rewolucji pisał w 1908 r.: „Po rewolucyjnych zapustach nastąpił wielki post - reakcya na całej linii" ${ }^{\prime 33}$. Nie tylko niemal nic nie zyskaliśmy, ale wręcz przeciwnie:

[...] rząd oprzytomniał i zebrał siły, - wziął się zaraz do tego co nazwał ,restitutio in integrum", do odbierania tego, co mu w chwili puszczenia cugli zostało wyrwane. To cośmy w ciągu dwóch lat otrzymali wskutek ogólnego przeobrażenia stosunków w państwie, zostało okrojone albo wstrzymane i sparaliżowane ${ }^{134}$.

Upadły więc jego krótkotrwałe nadzieje: ani rewolucja, ani „wielka klęska wojenna Rosyi nie zachwiała stanem jej posiadania na pograniczu zachodniem; nawet pod potężnemi uderzeniami młotów japońskich nie pękła ściskająca nas obręcz"135.

Przewartościowanie poglądów Piltza na kwestię niepodległości nastąpiło w latach I wojny światowej. Ówczesne jego stanowisko i działalność - od liczenia na zmianę stanowiska Rosji wobec Polski w czasie jej trwania i nadania jej autonomii, po opowiedzenie się za suwerennością - obszernie i szczegółowo opisał Andrzej Szczepaniak w pracy Od autonomii do niepodległości ${ }^{136}$, jak również Agnieszka Kidzińska, omawiając problematykę dotyczącą Stronnictwa Polityki Realnej i roli, jaką odgrywał w nim Piltz ${ }^{137}$. W tym miejscu, aby nie powtarzać treści wywodów zaprezentowanych przez tych autorów, należy tylko krótko podsumować ewolucję jego stanowiska.

${ }^{132} \mathrm{O}$ utworzeniu SPR i jego programie zob. Z. Markwart, Polityka realna ..., s. 137 i n.; A. Kidzińska, op. cit., s. 57 i n.

${ }^{133}$ SWL [E. Piltz], op. cit., s. 3. Zob. także: ibidem, s. 12-13; E. Piltz, O naszem stronnictwie..., s. 21.

${ }^{134}$ SWL [E. Piltz], op. cit., s. 7. Podobnie i z jeszcze większą goryczą pisał po kilku latach, gdy reakcja stołypinowska święciła tryumfy: „Po krótkim, niezapomnianym okresie, gdy zdawało się wypełniać marzenie, snute sto lat temu, [...] jak to kiedyś »wiatr zachodni« ogrzeje obszary rosyjskiego państwa; po latach rozpoczętych wojną - zakończonych konstytucją, które zwolniły zaciskającą nas obręcz [...] zaczęło się położenie nasze znowu pogarszać i aż do dziś pogarsza się stale. Rozluźniona obręcz zaciska się z powrotem. Wszystko, cośmy zdobyli w dniach wolnościowych, kurczy się; nad wszystkiem zawisła groźna niepewność. [...] Miecz znowu przeciw nam został wydobyty" (Tensam [E. Piltz], op. cit., s. 2-3).

135 SWL [E. Piltz], op. cit., s. 14.

136 A. Szczepaniak, Od autonomii do niepodległości..., s. 101-563.

${ }^{137}$ A. Kidzińska, op. cit., s. 175-295. 
W chwili wybuchu Wielkiej Wojny Piltz przebywał na kuracji w Niemczech, gdzie jako poddany rosyjski na krótko został internowany. Po zwolnieniu przyjechał do Lozanny, gdzie szybko nawiązał kontakty z Ignacym Paderewskim, Henrykiem Sienkiewiczem i innymi przebywającymi w Szwajcarii liderami polskiej emigracji. Mimo ciążącego odium ,ugodowca i „rusofila” rozpoczęli z nim współpracę, uznając go - jak Paderewski - za patriotę chcącego działać dla dobra Polski ${ }^{138}$. Zainicjował ,szereg instytucji o najrozmaitszej działalności”"139, m.in. charytatywnych, jak np. powołanie w styczniu 1915 r. w Vevey Komitetu Pomocy Ofiarom Wojny ${ }^{140}$. Aby wpływać na korzystne dla Polski stanowisko państw zachodnich i zainteresować kwestią polską ich rządy oraz elity, wykorzystując doświadczenia z pracy redaktorskiej, zredagował wydaną w języku francuskim encyklopedię dostarczającą wiedzę o kraju, jego historii, kulturze i uwarunkowaniach politycznych. Wysłano ją politykom państw Ententy oraz polskim (m.in. Paderewskiemu, Dmowskiemu), a także zachodnim publicystom ${ }^{141}$. Temu celowi miało też służyć utworzenie we wrześniu 1915 r. Centralnej Agencji Polskiej, której był pomysłodawcą, mającej być centrum inicjatyw propagujących sprawę polską na Zachodzie. Napisał jej program i objął stanowiska wiceprezesa zarządu i dyrektora, sprawując w niej faktyczne kierownictwo. Aby działać na rzecz umiędzynarodowienia sprawy polskiej, zamierzał stworzyć ponadorientacyjną reprezentację polską z centralą w Szwajcarii oraz z jej ekspozyturami w kilku stolicach europejskich i w USA, której zadaniem miało być wpływanie na polityków państw Ententy, a szczególnie francuskich, by wywierali presję na władze Rosji dla przyznania jej polskim poddanym praw narodowych, lecz ta jego inicjatywa nie została zaakceptowana.

${ }^{138}$ Określił go też jako „neofitę niepodległości”, lecz wiernego w działalności na rzecz Polski. Za: M. Leczyk, Komitet Narodowy Polski a Ententa i Stany Zjednoczone. 1917-1919, Warszawa 1966, s. 114. Zob. także: A. Szczepaniak, Od autonomii do niepodległości..., s. 136 i n.

${ }_{139}$ E. Piltz, Fakty i dokumenty dotyczace mojej działalności społecznej i politycznej za czas od 1882-1924, Warszawa 1924, s. 3.

${ }^{140}$ Opracował statut i był głównym organizatorem jego działalności. Z uwagi na postrzeganie go jako rusofila nie objął eksponowanego stanowiska, lecz został sekretarzem Komitetu, z czym wiązało się członkostwo w Radzie Wykonawczej i przewodniczenie Zgromadzeniu Generalnemu. Gwarantowało mu to faktyczne kierownictwo organizacją. Zob. W. Grabski, A. Żabko-Potopowicz, Ratownictwo spoleczne $w$ czasie wojny, [w:] Polska w czasie wielkiej wojny (1914-1918), t. 2: Historia społeczna, red. M. Handelsman, Warszawa 1932, s. 215-220; D. Płygawko, Sienkiewicz w Szwajcarii. Z dziejów akcji ratunkowej dla Polski w czasie I wojny światowej, Poznań 1986.

${ }^{141}$ To kompendium wiedzy o Polsce, opublikowane najpierw jako „mała” encyklopedia w październiku 1916 r., a następnie „wielka”, wzbudziło znaczne zainteresowanie. O pracach nad tym wydawnictwem zob. H. Florkowska-Frantič, Encyklopedie polskie na obczyźnie w latach I wojny światowej, [w:] Polonia wobec niepodlegtości Polski w czasie I wojny światowej, red. H. Florkowska-Frančić, H. Kubiak, M. Frančić, Wrocław 1979; A. Szczepaniak, Od autonomii do niepodległości..., s. 147 i n. Ten sam cel miało również wydane w maju 1915 r. streszczenie jego książki Polityka rosyjska w Polsce z 1909 r., opublikowane w języku francuskim (La politique russe en Pologne) z dostosowaną do nowych realiów przedmową. 
Wobec całkowicie zmienionej sytuacji politycznej spowodowanej wybuchem wojny, w której państwa zaborcze walczyły po obu stronach frontu, stanął wobec wyboru, za którą z dwóch przeciwstawnych orientacji się opowiedzieć. Mimo zawodu, jakiego doznał po analizie treści Manifestu ks. Mikołaja Mikołajewicza ${ }^{142}$, jednak był przekonany, że opcja prorosyjska jest korzystniejsza dla narodu, gdyż - podobnie jak wówczas Dmowski - jeszcze w niepodległość nie wierzy ${ }^{143}$. Sądził, że większym zagrożeniem będzie zwycięstwo Niemiec dominujących w bloku państw centralnych z powodu ich polityki germanizacyjnej. Uważał ponadto, że efektem jednoczesnej porażki dwóch spośród trzech zaborców będzie włączenie wszystkich ziem polskich do Rosji, co zmusi ją - z uwagi na liczebność narodu - do nadania mu autonomii. To określenie „zmusi” (mimo że jeszcze w 1904 r. krytykował za jego używanie Narodowych Demokratów) po raz pierwszy wyeksponował tak wyraźnie. Był jednak przekonany, że w przypadku zwycięstwa Ententy decydujący wpływ na losy Polski będzie miała Rosja, a bez jej akceptacji państwa koalicji niczego dla Polski nie uczynią. Podczas spotkań z Polonią apelował, aby nie opierać nadziei wyłącznie na Francji i Anglii i by nie drażnić Rosji, wysuwając publicznie hasła niepodległości ${ }^{144}$. Wydelegowany przez Sienkiewicza do Paryża, nawiązał kontakty z politykami francuskimi i nakłaniał polskie środowiska emigracyjne do solidarnej działalności na rzecz kwestii polskiej. Był pomysłodawcą i współautorem wielu memoriałów adresowanych do rządów i polityków Rosji i innych państw Ententy.

Przekonanie Piltza o potędze Rosji zmieniła ucieczka jej armii i władz z Królestwa po klęsce w maju 1915 r. Skłoniło go to do uwzględnienia znaczniejszej roli zachodnich sojuszników, co zbliżyło go do koncepcji Dmowskiego, z którym wkrótce, mimo wcześniejszej wrogości politycznej, nawiązał współpracę. Jego poglądy na przyszłość Polski zaczęły wówczas ewoluować. W opracowanej na podstawie jego projektu deklaracji utworzonego przez niego przy CAP tajnego Koła Politycznego w Lozannie ${ }^{145}$ stwierdzono, że celem polityki polskiej powinno być po pokonaniu Niemiec zjednoczenie wszystkich ziem polskich i uzyskanie od państw sojuszniczych wyraźnej deklaracji, że za zgodą Rosji zostanie z nich utworzone państwo polskie ${ }^{146}$. Dmowski, doceniając wybitne kwalifikacje Piltza i to, że miał bardzo dobre osobiste stosunki we francuskich sferach rządowych i dziennikarskich, powierzył mu misję dyplomatyczną w Paryżu. Swą działalność prowadził tam dwutorowo, spotykając się z czołowymi politykami francuskimi

${ }^{142}$ Powstanie II Rzeczypospolitej. Wybór dokumentów 1866-1925, red. H. Janowska, T. Jędruszczak, Warszawa 1981, s. 223-224.

143 A. Szczepaniak, Od autonomii do niepodległości..., s. 104-105.

${ }^{144}$ Ibidem, s. 134.

145 Ibidem, s. 235.

${ }^{146}$ C. Kozłowski, Działalność polityczna Koła Międzypartyjnego latach 1915-1918, Warszawa 1967, s. $87-88$. 
i rosyjskimi. Tych pierwszych usiłował nakłonić, wobec zajęcia przez państwa centralne ziem Królestwa, do wystosowania przez państwa koalicji oficjalnej deklaracji, w której jednoznacznie wypowiedzą się co do przyszłości Polski ${ }^{147}$. Z drugiej strony, spodziewając się odzyskania przez Rosję ziem Królestwa w wyniku przygotowywanej kontrofensywy, opracował dla ambasadora rosyjskiego Izwolskiego memoriał, w którym postulował, aby Cesarz wydał akt określający ustrój tymczasowej administracji wojennej. Władzę polityczną miały sprawować rosyjskie władze wojskowe, natomiast samorząd, oświata i sądownictwo powinny być przekazane Polakom. W kolejnym dostarczonym P. Milukowi memoriale stwierdził, że nadal liczy na rozwiązanie sprawy przyszłości Polski w oparciu o Rosję współdziałającej z mocarstwami zachodnimi ${ }^{148}$, lecz proponowany przez partię „kadetów” projekt przewidujący dla ziem polskich status autonomicznej prowincji Imperium znacząco odbiega od oczekiwań narodu. Jego zabiegi nie przyniosły rezultatów, bo Rosja nadal uważała, że kwestia polska jest jej wewnętrzną sprawą, a - jak przekonał się podczas rozmów z zachodnimi politykami - alianci, nie chcąc stracić rosyjskiego sprzymierzeńca, nie zamierzali naciskać na Petersburg.

Do kolejnego zweryfikowania poglądów na cele polskiej polityki zmusiła Piltza radykalnie zmieniona sytuacja po „Akcie 5 listopada” 1916 r., w którym cesarze Niemiec i Austro-Węgier ogłosili reaktywację państwa polskiego, co spowodowało umiędzynarodowienie kwestii niepodległości Polski. Uważał, że bardzo groźnym skutkiem tej deklaracji jest to, że projektowane państwo miało obejmować tylko terytoria Królestwa odebrane Rosji, co było sprzeczne z oczekiwanym zjednoczeniem wszystkich ziem polskich ${ }^{149}$, a ponadto, że tworzenie polskich organów administracji przez państwa centralne, których nie uznawał za reprezentacje narodu, zrewiduje stosunek części narodu do państw zaborczych. W związku z tym, pozostając nadal zwolennikiem koncepcji oparcia spraw polskich o Rosję, uważał, że należy próbować wykorzystać tę sytuację i silniej oddziaływać na carat, by pod jego egidą odbudować polską państwowośćc ${ }^{150}$. W styczniu 1917 r. ponownie postulował zjednoczenie ziem polskich i utworzenie z nich państwa konstytucyjnego związanego z Rosją węzłami dynastycznymi ${ }^{151}$. Podobne stanowisko prezentował w memoriale do władz rosyjskich, które przekazał ambasadorowi M. Giersowi podczas spotkania w Rzymie, gdzie także złożył wizyty papieżowi Benedyktowi XV

${ }^{147}$ M. Seyda, Polska na przełomie dziejów. Fakty i dokumenty, t. 1, Poznań 1927-1931, s. 557; M. Leczyk, op. cit., s. 49-50.

${ }^{148}$ M. Seyda, op. cit., s. 624-625; A. Lednicki, Pamiętnik 1914-1918, Kraków 1994, s. 78-79.

Więcej zob. A. Szczepaniak, op. cit., s. 257 i n.

${ }_{149}$ A. Kidzińska, op. cit., s. 222.

${ }^{150}$ M. Seyda, op. cit., s. 603-604, 607-608.

${ }^{151}$ M. Leczyk, op. cit., s. 61. 
i politykom włoskim ${ }^{152}$. Większą szansę na zrealizowanie swojej koncepcji Piltz dostrzegł po obaleniu caratu w wyniku rewolucji lutowej 23 lutego (8 marca) $1917 \mathrm{r}$. i utworzeniu rządu republikańskiego. Proponował wówczas, aby oprócz nacisków na koalicjantów wyraźnie zadeklarować prawo Polaków do własnej państwowości, a przede wszystkim by wpływać w tej sprawie na nowy rząd rosyjski. Dlatego w marcu wystosował we własnym imieniu memoriał do premiera ks. Lwowa, w którym apelował, by demokratyczna Rosja uznała prawo narodu polskiego do posiadania państwa ${ }^{153}$. Tu pojawiło się u niego pierwszy raz tak jednoznaczne opowiedzenie się za niepodległością. Wkrótce, zgodnie z jego ideą polityki realnej zakładającą dostosowywanie celów do aktualnych warunków politycznych, znów przewartościował swą koncepcję polityczną i bardziej zbliżył się do prozachodniej opcji proponowanej przez Dmowskiego. Postulował, by alianci solidarnie wydali akt gwarantujący Polsce niepodległość, nie bacząc już na to, co sądzi o tym rząd rosyjski, i aby uznali, że jednym z celów wojny jest utworzenie wolnej Polski ${ }^{154}$. Celowi wzmocnienia siły oddziaływania na państwa Ententy miało służyć powołanie 15 sierpnia Komitetu Narodowego Polskiego z siedzibą w Paryżu, którego był jednym z pomysłodawców i założycieli. Wszedł w jego skład jako członek Biura Prezydialnego i kierownik Wydziału Prawno-Politycznego.

Po przewrocie bolszewickim z dnia 24/25 października (6/7 listopada) $1917 \mathrm{r}$. definitywnie porzucił orientację prorosyjską. Stało się tak przede wszystkim dlatego, że od zawsze uważał rewolucyjny socjalizm za wielkie zagrożenie i odtąd nieograniczona jakimkolwiek związkiem z Rosją niepodległość stała się głównym celem jego działalności. Uważając, że w wyniku istnienia wojsk polskich walczących po stronie państw centralnych może zostać zmobilizowany milion polskich żołnierzy, rozpoczął starania o stworzenie armii polskiej u boku Francji pod zwierzchnictwem politycznym KNP ${ }^{155}$.

W obliczu zbliżającego się końca wojny, a szczególnie po pokoju podpisanym przez Rosję sowiecką z Niemcami i Austro-Węgrami w Brześciu, w którym przyznano Chełmszczyznę Ukrainie ${ }^{156}$, coraz bardziej aktualna stawała się kwestia

${ }^{152}$ O jego misji zob. A. Szczepaniak, Od autonomii do niepodległości..., s. 272 i n.

${ }^{153}$ E. Piltz, Fakty $i$ dokumenty..., s. 4-5. Jak pisze A. Szczepaniak (Od autonomii do niepodległości..., s. 321): „Trudno przecenić wpływ memoriału Piltza na ogłoszone 30 marca 1917 r. przez Rząd Tymczasowy oświadczenie Rządu dotyczące Polski”, wyrażające zgodę na jej prawo do suwerenności.

${ }^{154}$ M. Leczyk, op. cit., s. 76.

${ }^{155}$ O polskiej armii we Francji zob. m.in. Sclavus [W. Gąsiorowski], Historia Armii Polskiej we Francji 1910-1915, Warszawa 1931; M. Wrzosek, Polski czyn zbrojny podczas pierwszej wojny światowej 1914-1918, Warszawa 1990; J. Zamoyski, Powrót na mapę. Polski Komitet Narodowy w Paryżu 1914-1919, Warszawa 1991, s. 52-53; A. Szczepaniak, Od autonomii do niepodległości..., s. 285-317.

${ }^{156}$ A.R. Kozłowski, Rok 1918 - niezapomniany Pokój Brzeski, [w:] Problematyka geopolityczna ziem polskich, red. P. Eberhardt, Warszawa 2008, s. 177-178. 
granic Polski. Według Piltza na jej terytorium powinny się znaleźć Górny Śląsk, część Dolnego Śląska i Wielkopolska, Prusy Zachodnie z Gdańskiem (Wschodnie miały być polskim protektoratem), a także Wołyń, Polesie, zachodnia mińszczyzna, grodzieńszczyzna, ziemia chełmińska i Galicja, natomiast Litwę i Kurlandię powinna łączyć z Polską unia ${ }^{157}$.

Mimo że wcześniejsze trwanie przy opcji prorosyjskiej zniechęcało do niego znaczną część emigracyjnych polityków, to jednak z upoważnienia KNP Piltz prowadził ożywioną działalność dyplomatyczną. Dmowski bowiem pomimo zadawnionej niechęci i różnicy poglądów uważał, że z uwagi na jego doświadczenie i zaufanie, jakim obdarzał go francuski MSZ, gdzie miał najmocniejszą pozycję spośród polskich polityków ${ }^{158}$, jest potrzebny do oddziaływania na tamtejsze władze. Dlatego powierzył mu kierownictwo misji Komitetu w Paryżu i reprezentowanie go wobec rządu. Sprawując tę funkcję, Piltz podejmował starania, by Francja wpłynęła na pozostałych koalicjantów w sprawie deklaracji na rzecz niepodległości Polski, m.in. reprezentując w maju 1918 r. KNP na francusko-brytyjskim spotkaniu przygotowawczym do zwołania międzysojuszniczej Najwyższej Rady Wojennej. W ostatnich dniach wojny Piltz, wobec nieobecności Dmowskiego, aż do jego powrotu faktycznie przewodniczył KNP, odgrywając główną rolę w kształtowaniu jego polityki i działalności.

Po zakończeniu działań wojennych i po uznaniu na jego apel przez Francję Komitetu za rząd sensu stricto, uczestniczył w konferencji pokojowej jako szef wydziału politycznego w Biurze Prac Kongresu. Podczas częstych nieobecności ówczesnego premiera I. Paderewskiego kilkakrotnie przemawiał - oprócz Dmowskiego - w czasie obrad. Z upoważnienia rządu został oficjalnym reprezentantem Polski we Francji do czasu mianowania ambasadora i pełnił tę funkcję do czerwca 1919 r. ${ }^{159}$

W niepodległej Polsce Piltz działał na rzecz wzmocnienia międzynarodowej pozycji Polski, kontynuując trwającą do 1924 r. pracę w służbie dyplomatycznej jako dyrektor Departamentu Politycznego MSZ, a od kwietnia do maja 1921 r. jako wiceminister. Naczelnik Państwa Józef Piłsudski - wcześniej bezwzględnie go zwalczający - mianował go posłem w Belgradzie, na co wpłynął niewątpliwie fakt znajomości z tamtejszymi politykami. Sprawując tę funkcję (od września 1919 r. do lutego 1920 r.), starał się m.in. osłabić prorosyjską agitację rosyjskich „białych” emigrantów ${ }^{160}$. W kolejnych latach zajmował się przede wszystkim po-

${ }^{157}$ O poglądach Piltza na kształt granic zob. A. Szczepaniak, Od autonomii do niepodległości ..., s. 383-400. Zob. także: M. Leczyk, op. cit., s. 58-59, 74-75.

158 A. Deruga, Polityka wschodnia Polski wobec ziem Litwy, Białorusi i Ukrainy (1918-1919), Warszawa 1969, s. 110.

159 J. Łaptos, Dyplomaci II RP w świetle raportów Quai d'Orsay, Warszawa 1993, s. 50.

160 A. Szczepaniak, Działalność dyplomatyczna Erazma Piltza w Belgradzie (26 VI 1919 - 20 III 1920), [w:] Między Europa naszych pragnień a Europa naszych możliwości, red. J. Faryś, T. Sikorski, P. Słowiński, t. 2, Gorzów Wielkopolski 2007, passim. 
dejmowanymi już w czasie wojny staraniami o uregulowanie stosunków z Czechosłowacją, wykorzystując od dawna utrzymywane kontakty z czeskimi politykami (Edwardem Beneszem i Tomaszem Masarykiem), którzy postrzegali go jako przyjaciela Czech. Chciał doprowadzić do jej przymierza z Polską, lecz na przeszkodzie stał konflikt o Śląsk Cieszyński i Jaworzynę oraz daleko idące roszczenia terytorialne zgłaszane w kulminacyjnym momencie wojny z Sowietami przez Benesza. W związku z tą sprawą Naczelnik Państwa wysłał go z misją do Paryża i na konferencję Rady Najwyższej do Spa, gdzie bezskutecznie, wobec oporu Benesza, usiłował skłonić obie strony do rozmów i aby zgodziły się na arbitraż. Zabiegał też o poparcie Francji i Włoch dla polskiego stanowiska. Fiaskiem skończyła się również jego działalność jako posła w Pradze (od lipca 1921 r. do grudnia 1922 r.). Usiłował także doprowadzić do zawarcia strategicznego sojuszu z Francją i Rumunią ${ }^{161}$. Piltz odegrał istotną rolę w negocjacjach z Francją, sfinalizowanych podczas wizyty Piłsudskiego w Paryżu w lutym 1921 r. zawarciem umów politycznej i gospodarczej oraz tajnej wojskowej. Kolejnym polem jego działalności były starania o nawiązanie współpracy z Włochami i pozyskanie ich neutralności w konflikcie polsko-litewskim po aneksji Wilna przez gen. Żeligowskiego ${ }^{162}$. Dalsza jego działalność w dyplomacji była już mniej znacząca. Nie przyjął proponowanego stanowiska ministra spraw zagranicznych, a ostatnie lata pracy w MSZ spędził jako konsultant do spraw politycznych.

Postać Piltza, ewolucja jego poglądów i wynikająca z niej działalność opierająca się o zasadę ,,polityki realnej”, a więc dostosowującej cele do aktualnej sytuacji politycznej i warunkujących ją możliwości, w tym wpływu kolejnych wojen na sytuację narodu, mogą być przyczynkiem do analizy postaw Polaków od lat 60. XIX w. po odzyskanie niepodległości. O ile w latach zaborów był symbolem znienawidzonej przez większość narodu ,ugody” z Rosją, uznając, że niemożliwe jest odzyskanie niepodległości, a w latach wojny rosyjsko-japońskiej i będącej jej skutkiem rewolucji 1905 roku postulował przyznanie Królestwu Polskiemu autonomii, o tyle podczas I wojny światowej i rewolucji oraz wojny domowej w Rosji dochodził stopniowo do stanowiska, że suwerenność jest najważniejszym celem polskiej polityki. Chciał ją odzyskać najpierw pod egidą Rosji, a następnie - po

${ }^{161}$ A. Essen, Polska a Mała Ententa 1920-1934, Warszawa-Kraków 1975, s. 27-29, 34, 47, 52-54. O jego zabiegach o uregulowanie stosunków z Czechosłowacją zob. m.in. A. Szczepańska, Czechostowacja w polskiej polityce zagranicznej, Szczecin 2004; A. Szklarska-Lohmannowa, Polsko-czechostowackie stosunki dyplomatyczne w latach 1918-1925, Wrocław-Warszawa 1967; A. Szczepaniak, Od autonomii do niepodległości ..., s. 445-516.

${ }^{162}$ S. Sierpowski, Stosunki polsko-włoskie w latach 1918-1940, Warszawa 1975, s. 79; J. Łaptos, op. cit., s. 98; A. Szczepaniak, Od autonomii do niepodlegtości..., s. 438 i n. 
przewrocie bolszewickim - przy pomocy państw zachodnich. W II Rzeczypospolitej, zajmując znaczące stanowiska $w$ dyplomacji, działał na rzecz umocnienia pozycji międzynarodowej Polski. Symptomatyczne jest to, że mimo iż był wcześniej bezwzględnie zwalczany przez Romana Dmowskiego i Józefa Piłsudskiego, to potrafił dla dobra Polski z pierwszym z nich - mimo rywalizacji w KNP - ściśle współpracować, a ten drugi, który bezpardonowo go niegdyś atakował, powierzał mu znaczące stanowiska w dyplomacji. Uznając jego znaczący wkład w działania na rzecz niepodległego państwa, II Rzeczpospolita nadała mu Order Polonia Restituta i najwyższe odznaczenie - Order Orła Białego. Jego zasługi zostały też docenione za granicą - Prezydent Francji przyznał mu order Legii Honorowej, a władze Rumunii - Order Lwa Białego i Korony Rumuńskiej ${ }^{163}$.

\section{BIBLIOGRAFIA}

\section{Archiwa}

Archiwum Akt Nowych, Komitet Narodowy Polski, sygn. 2205, k. 2.

\section{Czasopisma}

„Kraj” 1890, nr 29 (20 lipca / 1 sierpnia).

„Kraj” 1896, nr 48 (29 września / 11 grudnia).

„Kraj” 1904, nr 10 (5 / 18 marca).

„Kraj” 1904, nr 39 (24 września / 7 października).

„Kraj” 1905, nr 11 (18 / 31 marca).

„Kraj” 1905, nr 18 (6 / 19 maja).

„Kraj” 1905, nr 32 (12 / 25 sierpnia).

„Kraj” 1905, nr 42 (24 października / 6 listopada).

„Przegląd Wszechpolski” 1904, nr 7.

\section{Literatura}

Deruga A., Polityka wschodnia Polski wobec ziem Litwy, Białorusi i Ukrainy (1918-1919), Warszawa 1969.

Essen A., Polska a Mała Ententa 1920-1934, Warszawa-Kraków 1975.

Feldman W., Dzieje polskiej myśli politycznej 1864-1914, Warszawa 1933.

Florkowska-Frantič H., Encyklopedie polskie na obczyźnie w latach I wojny światowej, [w:] Polonia wobec niepodległości Polski w czasie I wojny światowej, red. H. Florkowska-Frančić, H. Kubiak, M. Frančić, Wrocław 1979.

Grabski W., Żabko-Potopowicz A., Ratownictwo spoleczne w czasie wojny, [w:] Polska w czasie wielkiej wojny (1914-1918), t. 2: Historia społeczna, red. M. Handelsman, Warszawa 1932.

Kidzińska A., Stronnictwo Polityki Realnej 1905-1923, Lublin 2007.

Kmiecik Z., , Kraj” za czasów redaktorstwa Erazma Piltza, Warszawa 1969.

Kmiecik Z., Nowoczesny konserwatysta (Erazm Piltz), „Kwartalnik Historii Prasy Polskiej” 1991, z. $3-4$.

Kozłowski A.R., Rok 1918 - niezapomniany Pokój Brzeski, [w:] Problematyka geopolityczna ziem polskich, red. P. Eberhardt, Warszawa 2008.

${ }^{163}$ Ostatnie lata działalności Piltza opisał A. Szczepaniak (Od autonomii do niepodległości..., s. $517-563)$. 
Kozłowski C., Działalność polityczna Koła Międzypartyjnego latach 1915-1918, Warszawa 1967.

Krzywoszewski S., Dlugie życie. Wspomnienia, t. 1, Warszawa 1947.

Leczyk M., Komitet Narodowy Polski a Ententa i Stany Zjednoczone. 1917-1919, Warszawa 1966. Lednicki A., Pamiętnik 1914-1918, Kraków 1994.

„Listy Polskie”. Zeszyt próbny pisma poświęconego sprawom politycznym polskim w ogóle i sprawom Królestwa w szczególności, Kraków 1904.

Łaptos J., Dyplomaci II RP w świetle raportów Quai d'Orsay, Warszawa 1993.

Markwart Z., Państwa zaborcze i ich polityka wobec Polski w pogladach stronnictwa realistów, „Annales UMCS sectio G (Ius)” 2011, t. 58.

Markwart Z., Polityka realna. Zarys działalności i programu stronnictwa petersburskich realistów (1859-1906), Kraków 2012.

Markwart Z., Polityka rosyjska wobec Polski do I wojny światowej w ocenie petersbursko-warszawskich realistów, „Annales UMCS sectio G (Ius)” 2012, t. 59.

Markwart Z., Włodzimierz Spasowicz i petersburscy realiści: apostaci, ugodowcy czy rzecznicy narodu?, [w:] Między realizmem a apostazja narodowa. Koncepcje prorosyjskie w polskiej myśli politycznej, red. M. Zakrzewski, Kraków 2015.

Myśliński J., Grupy polityczne Królestwa Polskiego w Zachodniej Galicji 1895-1904, Warszawa 1967.

Pawłowski I., Stronnictwa i programy polityczne w Królestwie Polskim 1864-1918, t. 2, cz. 1: (1900-1907), Warszawa 1964.

Piltz E., Fakty i dokumenty dotyczace mojej działalności społecznej i politycznej za czas od 18821924, Warszawa 1924.

Piltz E., O naszem stronnictwie. Przemówienie Erazma Piltza na ogólnem zebraniu Stronnictwa Polityki Realnej odbytem w Warszawie 18 stycznia 1910 r., Warszawa 1910.

Piltz E., Politya rosyjska w Polsce. List otwarty do kierowników polityki rosyjskiej, Warszawa 1909.

Płygawko D., Sienkiewicz w Szwajcarii. Z dziejów akcji ratunkowej dla Polski w czasie I wojny światowej, Poznań 1986.

Powstanie II Rzeczypospolitej. Wybór dokumentów 1866-1925, red. H. Janowska, T. Jędruszczak, Warszawa 1981.

Sclavus [W. Gąsiorowski], Historia Armii Polskiej we Francji 1910-1915, Warszawa 1931.

Scriptor [E. Piltz], Nasze stronnictwa skrajne, Kraków 1903.

Seyda M., Polska na przełomie dziejów. Fakty i dokumenty, t. 1, Poznań 1927-1931.

Sierpowski S., Stosunki polsko-włoskie w latach 1918-1940, Warszawa 1975.

Spasowicz W., Fantazje polskie na tematy stowianofilskie, [w:] idem, Pisma, t. 2, Petersburg 1892.

Spasowicz W., Jerzego Moszyńskiego po czterdziestu latach. Szkic polskiej polityki o chwili obecnej, [w:] idem, Pisma, t. 9, Warszawa 1908.

Spasowicz W., Jubileusz Kraszewskiego, [w:] idem, Pisma, t. 6, Petersburg 1892.

Spasowicz W., Polityka samobójstwa, samobójstwa. Uwagi nad pisemkiem „,Polska i Rosja w 1872 przez b. członka Rady Stanu Królestwa Polskiego”, Poznań 1872.

SWL [E. Piltz], Obrachunek, Poznań 1908.

Swojak [E. Piltz], Wobec wojny. Głos z Warszawy przez Swojaka, Kraków 1904.

Szczepaniak A., Dzialalność dyplomatyczna Erazma Piltza w Belgradzie (26 VI 1919- 20 III 1920), [w:] Między Europa naszych pragnień a Europa naszych możliwości, red. J. Faryś, T. Sikorski, P. Słowiński, t. 2, Gorzów Wielkopolski 2007.

Szczepaniak A., Od autonomii do niepodległości. Działalność polityczna Erazma Piltza w latach 1914-1929, Opole 2015.

Szczepańska A., Czechostowacja w polskiej polityce zagranicznej, Szczecin 2004.

Szklarska-Lohmannowa A., Polsko-czechostowackie stosunki dyplomatyczne w latach 1918-1925, Wrocław-Warszawa 1967.

Szwarc A., Od Wielopolskiego do Stronnictwa Polityki Realnej. Zwolennicy ugody z Rosją. Ich poglady i próby działalności politycznej (1864-1905), Warszawa 1990. 
Tensam [E. Piltz], W chwili ciężkiej i trudnej, Warszawa 1912.

Wrzosek M., Polski czyn zbrojny podczas pierwszej wojny światowej 1914-1918, Warszawa 1990.

Zamoyski J., Powrót na mapę. Polski Komitet Narodowy w Paryżu 1914-1919, Warszawa 1991.

\section{SUMMARY}

Erazm Piltz (1851-1929), one of the leaders of the realist fraction thought that after the January Uprising of 1863 there was no chance that Poland would regain sovereignty. All attempts to defend, and later to regain, independence had ended with a defeat. Each and every next uprising brings a threat of an extermination of the nation, especially that Western countries would not militarily help, since they would not want to start a war with the countries that had partitioned Poland. There is also no chance of a conflict between those countries. That is why Piltz was convinced that legal methods should be used to try to ensure the best possible conditions for the nation's existence in each of the partitions. He saw a chance to ameliorate the situation of the Poles in the Kingdom of Poland only in reforming Russian political system, especially during the 1905-1907 revolution that was an effect of the war between Russia and Japan. Similarly during the First World War he argued in favour of such a solution. In time his views evolved and starting from the 1917 revolution he noticed a chance for Poland's sovereignty, yet still under Russia's protection. He abandoned this view after the Bolshevik revolution of November 1917. From that moment, as a part of the Polish National Committee, he acted in favour of regaining independence. During the period of the Second Republic of Poland he exercised numerous functions as a diplomat and tried to enforced Poland's international position.

Keywords: Polish political thought of the $19^{\text {th }}$ and $20^{\text {th }}$ centuries; Erazm Piltz; realist fraction; wars and national uprisings and Poland's independence; Russian-Japanese war; World War I and Poland's issue

\section{STRESZCZENIE}

Erazm Piltz (1851-1929), jeden z liderów stronnictwa „realistów”, zaliczany do tzw. nurtu „ugody” z Rosją uważał, że po powstaniu 1863 r. nie ma szans na suwerenność Polski. Wszystkie próby obrony, a następnie jej odzyskania środkami militarnymi skończyły się klęską. Każde kolejne powstanie zagraża zagładą narodu, a państwa zachodnie nie udzielą pomocy militarnej, gdyż nie zdecydują się na wojnę z zaborcami. Nie dojdzie też do konfliktu między nimi. Dlatego był przekonany, że należy legalnymi środkami starać się o zapewnienie jak najlepszych warunków bytu narodu w każdym z zaborów. Szanse na jego poprawę w Królestwie Polskim widział jedynie w przypadku zreformowania ustroju Rosji, szczególnie w czasie rewolucji 1905-1907, będącej efektem wojny rosyjsko-japońskiej. Podobnie w latach I wojny światowej opowiadał się za takim rozwiązaniem. Z czasem jego poglądy zaczęły ewoluować i od rewolucji 1917 r. dostrzegał szansę na odbudowę suwerenności, lecz także pod egidą Rosji. Opcję tę porzucił po przewrocie bolszewickim z listopada 1917 r. Od tej pory w ramach Komitetu Narodowego Polskiego działał na rzecz uzyskania niepodległości, a w II Rzeczypospolitej, pełniąc szereg funkcji w dyplomacji, starał się wpływać na umocnienie jej pozycji międzynarodowej.

Słowa kluczowe: Polska myśl polityczna XIX i XX w.; Erazm Piltz; stronnictwo „realistów”; wojny i powstania narodowe a niepodległość Polski; wojna rosyjsko-japońska; I wojna światowa a sprawa polska 